Int. J. Dev. Biol. 57: 241-253 (2013)

doi: 10.1387/ijdb.13002611

\title{
Development of malignant germ cells - the genvironmental hypothesis
}

\author{
LEENDERT H.J. LOOIJENGA*, TON VAN AGTHOVEN and KATHARINA BIERMANN \\ Department of Pathology, Erasmus MC - University Medical Center Rotterdam, Josephine Nefkens Institute, \\ Daniel den Hoed Cancer Center, Rotterdam, The Netherlands
}

\begin{abstract}
Human germ cell tumors are of interest because of their epidemiology, clinic and pathobiology. Histologically, they are subdivided into various elements, with similarities to embryogenesis. Recent insight triggered development of a higher order division into five types of human germ cell tumors. In the context of male germ cells, only three are relevant; Type I: teratomas and yolk sac tumors of neonates and infants; Type II: seminomas and nonseminomas of (predominantly) adolescents and adults; and Type III: spermatocytic seminomas of the elderly. Various animal models, both occurring spontaneous or induced, are reported, of which their relevance is still a matter of debate. Recent multidisciplinary studies have led to a significant increase in our understanding of the parameters involved in the earliest pathogenetic steps of human germ cells tumors, particularly the seminomas and nonseminomas (Type II).This paper will discuss a number of interesting insights into the normal and aberrant regulation of germ cell development, resulting in the so-called genvironmental hypothesis. This assumes a subtle interaction between environmental- and (epi)genetic parameters, resulting in clinical/phenotypical characteristics. These influence signaling pathways and thereby developmental processes, including gonadal development, germ cell proliferation, maturation and apoptosis. In the case of a disturbed physiology, either due to the germ cell itself, or the micro-environment, embryonic germ cells, during a specific window of sensitization, might be blocked in their maturation, resulting in carcinoma in situ or gonadoblastoma, the precursors of seminomas and nonseminomas. The level of testicularization of the gonad determines the histological composition of the precursor. These insights will allow a better definition of individuals at risk of developing a germ cell malignancy, and allow a better selection of scientific approaches to elucidate the corresponding pathogenesis.
\end{abstract}

KEY WORDS: testis, gonad, germ cell tumor, environment

\section{Introduction}

To date increasing attention is given to elucidate the pathogenesis and clinical behavior of human germ cell tumors (GCT). In this context, proper classification into subgroups is relevant, particularly because various spontaneous and induced animal models are given a prominent place in the scientific scene. In spite of their potential informative status, they are not by definition representative for (all variants of) human GCT. The current interest in GCT can be explained by a number of reasons. These relate to recent ideas about the origin and progression of cancer in general, as well as long term side effect of systemic treatment on individual cancer patients. This strengthens the need for individualized and possibly tailored treatment. Indeed, human GCT show a set of unique characteristics that may shed novel light on these specific processes. In addition, and possible one of the major explanatory arguments for the increasing attention, is that GCT mimic normal embryonic development. They show regulatory processes involved in proliferation, differentiation, as well as apoptosis. It is often difficult to separate whether the observations made in GCT are intrinsic to the cell of origin and therefore representative for behavior of the different derivatives present, or related to mechanisms involved in the process of malignant transformation. In spite of this limitation, interesting findings can be obtained (Spiller et al., 2012,

Abbreviations used in this paper: GCT, germ cell tumor; NGS, next generation sequencing; PGC, primordial germ cell; SNP, single nucleotide polymorphism; TSPY, Testis Specific Protein on the Y chromosome.

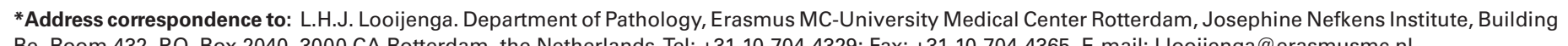
Be, Room 432, P.O. Box 2040, 3000 CA Rotterdam, the Netherlands. Tel: +31-10-704-4329; Fax: +31-10-704-4365. E-mail: I.looijenga@erasmusmc.nl 
Westerman et al., 2011). The items of interest related to GCT to clinicians, scientists, and patients, deal will increasing knowledge about behavior of stem cells, i.e., embryonic-, adult- and cancer-, as well as their unique histology-related pattern of sensitivity and resistance to DNA damaging agents. Several of these aspects will also be discussed in other papers within this Special Issue. Moreover, GCT represent a wonderful model to study the putative interaction(s) between germ cells and their micro-environment, being under strict (interactive) control of genetic-, epigenetic-, and environmental parameters (Spradling et al., 2011). Moreover, GCT are predominantly diagnosed in relatively young patients, i.e., neonates and infants, as well as adolescents and young adults, with major mental (short and long term), physical, social, and even economical impact. Significant numbers of patients require surgery followed by either systemic treatment (irradiation and/or chemotherapy), with proven long term effects on quality of life. Risk factors for development of specific subgroups of GCT have been identified, which are useful to identify groups within the general population with an increased risk to develop this type of cancer. These findings potentially allow selection of individuals for (targeted) screening, with potential early diagnosis and treatment, preventing long term effects of systemic treatment.

In this manuscript, an update on the current knowledge on the pathogenesis of human GCT will be given, in which relevant information about normal germ cell development and well as animal models, will be included. Some of these topics will be more extensively discussed in other papers within this Special Issue, therefore only briefly touched upon here. Finally, the most relevant hypothesis to be tested in the context of the origin of the GCT of adolescents and adults, i.e., the seminomatous and nonseminomatous tumors, according to these authors, will be presented. It includes a subtle interplay between genetic-, epigenetic-, and (micro-)environmental parameters, referred to as GENVIRONMENT, as the major mechanism in determining the embryonic germ cell stem niche, being therefore more or less susceptible for events involved in the process of malignant transformation, eventually leading to the precursor lesions and progression to full blown malignancy. Before going into more detail, the rationale to subdivide human GCT will be explained.

\section{Heterogeneity of human germ cell tumors? Relevance of sub-classification}

The traditional approach to classify human and animal GCT is based on histological characterization, preferentially done by a ( $\mathrm{n}$ experienced) pathologist. Identification of the various lineages of differentiation is predominantly based on morphological criteria, sometimes supported by application of immunohistochemical stainings. The markers Alpha Feto Protein (AFP) and human Chorionic Gonadotrophine (hCG) can be used for immunohistochemical detection on tissue sections to identify yolk sac tumor and choriocarcinoma components, respectively. In addition, they are routinely used as serum markers. In addition, a large number of more recent markers have been identified and applied, some of them highly useful (to be discussed below). These markers are predominantly recognized as being of potential interest based on increasing knowledge derived for studying normal embryonic development, both murine and human. The majority of these markers support the expected histological composition of the lesion based on morphological evaluation, with often significant overlap. However, application of these markers in a routine diagnostic procedure allows a (more) straight-forward, relatively fast and reproducible identification/diagnosis of the histological composition present. In spite of this significant improvement, "simple" processing of the samples and characterization of the various histological elements present according to this approach is not representing optimal classification of GCT in the context of their heterogeneous origin and (related) pathogenesis. This is however required to allow proper selection of the samples for scientific and clinical studies, without comparing non-related (sub)groups and dilution potential important findings. Therefore we proposed in 2005 an alternative model for the classification of GCT, which will be presented and discussed in the next paragraph.

\section{Patho-biological classification of GCT}

Based on a defined set of criteria, five types of GCT can be distinguished. The informative parameters to distinguish these entities are anatomical site and age of clinical presentation, precursor lesion (cell of origin and intrinsic pattern of genomic imprinting), as well as chromosomal constitution. The different entities include the Type I: teratomas and yolk sac tumors of neonates and infants; Type II: seminomatous and nonseminomatous GCTs of mainly adolescents and young adults; Type III: spermatocytic seminomas of the elderly testis; Type IV: dermoid cysts, mainly the ovary; and Type V: the hydatiform mole in fertile woman. Within the context of male germ cells, only the Type I, II and III GCT are of relevance, and will therefore be discussed in more detail here. The subdivision as proposed is in line with results of detailed description of spontaneous as well as induced animal models for GCT. Before going into detail regarding the three types of human GCT, the most relevant animal models in this perspective (according to the authors) will be presented.

\section{Animal models of human GCT; an introduction}

Alarge and heterogeneous series of studies have been reported related to possible animal models for human GCT, spontaneously occurring and induced by laboratory manipulations. The major findings related to the current topic will be discussed here, focusing on five species: Caenorhabditis Elegans (nematode), Drosophila Melanogaster (fruit fly), zebrafish, mouse and dog. These will be presented subsequently, after which an overall interpretation on their relevance for human GCT will be given.

\section{Caenorhabditis (C.) elegans}

C. elegans is a highly informative animal model to study normal and aberrant development, including cancer, even GCT (Berry et al., 1997, Subramaniam and Seydoux, 2003). PUF-8 knock outs resulted in GCT (Subramaniam and Seydoux, 2003), histologically showing similarities to spermatogonia. PUF proteins are RNA binding proteins regulating RNA stability and translation, found to be crucial in germ line stem cell self-renewal. It is demonstrated that PUF-8 is required to complete meiotic prophase. Absence will result in dedifferentiation, leading to tumors composed of mitotic undifferentiated germ cells. Another model of GCT in this species is related also to a RNA interacting component. GLD-1 has been found to be related to regulation of mitosis and meiosis (Crittenden 
et al., 1994, Francis et al., 1995) and GCT formation (Berry et al., 1997). This regulates cell cycle, specifically via cyclin $E$ and Cdk2 (Jeong et al., 2011). Interestingly, GLD-1 is involved in the inhibition of the translation of cyclin E mRNA towards protein (functions as a physiological si-RNA). This results in prevention of re-entry of mitosis of germ cells. In case of GLD-1 absence, cyclin E protein is formed, resulting in re-entry of the cell cycle, and a transition to a somatic lineage, resulting in teratoma, i.e., representing somatic differentiation (Biedermann et al., 2009). In other words, two variants of GCT can be generated in this species, one still showing similarities to the germ cell lineage, and the other showing so-called activation of pluripotency, also known as undergoing the process of reprogramming, i.e., transition to a somatic lineage.

\section{Drosophila (D.) melanogaster}

As for $C$. elegans, $D$. melanogaster has also been proven to be an informative source of relevant information related to normal and aberrant development, including germ cell behavior and gonadal formation (Decotto and Spradling, 2005, Jaglarz and Howard, 1994, Tran et al., 2000), as well as GCT (Gonczy et al., 1997, Hime et al., 2007). Again, cyclin E is found to be related to cell cycle regulation, and down-regulation is required for normal germ cell cycle arrest (Knoblich et al., 1994). Neural insulin-like peptides have been found to regulate germ line stem cells influenced by diet (Hsu et al., 2008). These factors specifically target the $\mathrm{G}_{2}$ phase of the cell cycle under control of the signaling pathways $\mathrm{PI}_{3} \mathrm{~K}$ and FOXO (to be discussed in more detail later). In addition the transition related to the $G_{1}$ phase of the cell cycle is also influenced by diet. GCT in this animal, showing histological similarities of to the germ cell lineage, are still responding to this signaling pathway, suggesting that it is a germ cell intrinsic response, independent of the niche. In addition, PTEN, LKB1 and AMPK are found to regulate $P G C$ proliferation is this species (Narbonne and Roy, 2006). Increasing information is becoming available that the supportive cells in the niche are also required to allow maturation of the stem cells to happen (Srinivasan et al., 2012). In other words, a subtle balance between inducing and inhibiting factors seems to determine the cell fate.

\section{Zebrafish}

Recent studies have shown that zebrafish is an informative model for embryogenesis and cancer development (Amatruda et al., 2002). Using a mutagenic approach, an interesting and first model of GCT in zebrafish has been generated. Forward genetic approaches showed that inactivation of Alk6, a type I Bone Morphogenic receptor, results in activation of the Smad pathway in male germ cells, and tumors composed of pre-meiotic germ cells are formed (Neumann et al., 2011a, Neumann et al., 2011b), still showing germ cell lineage characteristics.

\section{Mouse}

The initial studies on GCT in mouse were performed by Stevens, who demonstrated that the 129 strain mouse specifically has a high tendency to develop teratomas, originating from embryonic germ cells (Stevens, 1970, Stevens and Varnum, 1974, Walt et al., 1993). In fact, this is the model that always includes loss of germ cell characteristics, and gain of the somatic lineage profile as part of the process of tumorigenesis. These studies initiated a large series of very interesting studies. The specific susceptibility of the
129 strain for GCT development, genetically associated with Ter, is linked to a RNA modifying gene (Kedde et al., 2007), called Dnd (Dead End) (Youngren et al., 2005). Interestingly, Dnd is involved in regulation of generation of mature miRNAs (Ketting, 2007). Most recently, an interaction between Dnd and the RNA binding unit of ApoB editing complex is demonstrated (Nelson et al., 2012). This is regulating the actual risk for GCT development (i.e. teratomas), both in a conventional as well as transgenerational manner. In addition, it has been elegantly demonstrated that the Kit-Kitlg (Stem Cell Factor) pathway is involved in development of these types of teratomas in the 129 strain (Heaney et al., 2008). Loss of the soluble ligand (Kitlg) has no effect on tumor formation, while loss of the membrane bound variant increases the risk. This is particularly of importance in the context of the role of this particular pathway in the migration, proliferation and survival of mouse PGC (Runyan et al., 2006, Wylie, 1999). In comparison to Drosophila, it has been demonstrated that Igf- 1 is secreted by mouse Leydig cells which is a key determinant in retaining pluripotency germ line stem cells (GSC), characterized by their alkaline phosphatase activity, as well as expression of OctT3/4, Blimp-1 and Nanog (Huang et al., 2009). This system functions again via the $\mathrm{PI}_{3} \mathrm{~K}$ pathway (see above). In contrast to the teratomas in mouse, also other types of GCT are reported in this species, although exceptionally. For example, a seminomatous like tumor is generated from genomic imprint-free embryonic stem cells (Holm et al., 2005), found to be related to aberrant activation of the TGF $\beta$ pathway. This indicates that proper erasement and establishment of a uniparental (paternal) pattern of genomic imprinting is crucial for normal germ cell maturation origin (Looijenga et al., 1998). Nodal signaling has been found to regulate developmental potential of mouse germ cells as well, which interestingly is reflected in human GCT as well (Spiller et al., 2012). This topic will be extensively discussed in a separate paper in this Special Issue (van der Zwan et al., 2013, Eini et al. 2013). A seminomatous-like tumor is also generated based on overexpression of cyclin D combined with activated Ras signaling (Lee et al., 2009). It still remains to be shown whether these models indeed present the Type II GCT, as diagnosed in humans.

The factor cyclin $\mathrm{E}$ is also found to be a significant player in the field of normal mouse development, including the germ cell lineage. It is involved in regulation of endoreplication of trophoblastic cells during normal development (Parisi et al., 2003). Over-expression of cyclin $E$ in spermatogonia results in reduced spermatogonial proliferation and reduced fertility (Liberal et al., 2010). In addition, down-regulation of cyclin E1 is specifically observed in male fetal germ cells during the 12.5-14.5 dpc period (Western et al., 2008). Unpublished data from our group show that upon tetraploidization of mouse ES cells, there is a significant and specific activation of the $\mathrm{PI}_{3} \mathrm{~K}$ pathway (Zanazzi and coworkers, unpublished data).

Knock out of Dmrt1 in embryonic male mouse germ cells is found to induce teratomas, in a dose specific manner (Krentz AD, 2009). Interestingly, Dmrt1 is one of the major regulators of gonadal sex determination (Matson et al., 2011, Matson and Zarkower, 2012), also relevant in the context of patients with Disorders of Sex Development (DSD) at risk for GCT development (see below). In fact, Dmrt1 prevents development of the ovarian lineage in the male chromosomal constitution (XY). In fact, it seems to be the male counterpart of the female Foxl2 signaling in ovarian development (Uhlenhaut et al., 2009, Uhlenhaut and Treier, 2006). The function of Dmnt1 is evolutionary conserved, based on the role of this 
gene in C. elegans and D. melanogaster (Raymond et al., 2000).

\section{Dog}

Spontaneous occurring GCT in dogs have been known for a long time (Schlotthauer, 1938, Scully and Coffin, 1961). This phenomenon has been investigated by various groups independently, using morphology alone, or including protein and mRNA expression profiles, as well as genetic constitution (Bush et al., 2011, Inoue and Wada, 2000, Looijenga et al., 1994, Murakami et al., 2001, Yu et al., 2009l). The overall conclusion is that canine GCT are relatively benign and are characterized by the presence of small, intermediate and large cells. So far, no specific signaling pathway of chromosomal anomaly has been linked to the development of this type of GCT in dogs.

\section{Interpretation of animal models for human GCTs}

The data available mainly support that most GCT in animals resulting in teratomas are resembling to the Type I GCTs of humans. Especially, data on the majority of mouse GCT support this notion, with the possible exception of the imprint-free ES derived and cyclin D overexpressing seminomatous-like tumors. Dnmt 1 is of particular interest, because it has been related with DSD, and linkage has been found in the general male population with risk of type II GCT of the testis (both items to be discussed below). Knowledge on the pathogenesis of GCT has increased are thinking strategies for develop safety regulations for human stem cell therapies (Cunningham et al., 2012).

The heterogeneity in genes of which disruption results in germ cell derived teratomas indicate that a transition to the somatic lineage is activated in affected undifferentiated germ cells as proposed before (Looijenga, 1999). Of specific interest is the fact that this repeatedly is found to be linked to regulation of the cell cycle. So far, no consistent genetic anomalies in type I GCT, especially teratomas have been found in humans (Linger et al., 2008). This might be due to the same underlying mechanism, resulting in a rather heterogeneous spectrum of potential targets (mRNA, miRNAs, proteins though genetic or epigenetic changes) involved.

Interestingly, in D. melanogaster, C. Elegans, as well as in mouse, cyclin $E$ has been related to normal germ cell development, as well as development of GCT. Again, a link with cell cycle regulation is becoming apparent. However, this might related to both in Type I- and Type II-GCT, requiring additional investigations. Indeed, cyclin $E$ has also been suggested to be relevant in the pathogenesis of human (type II) GCTs, both from the testis (Datta et al., 2000) and ovary (Kawauchi et al., 2006). In addition, cyclin $E$ is related to cisplatin resistance in a number of solid cancers (of epithelial origin: carcinomas), including those of the ovary (Etemadmoghadam et al., 2009, Nakayama et al., 2000). Moreover, we identified a chemotherapy resistant metastatic (late age metastatic Type I) GCT, composed of teratoma and yolk sac tumor, with specific amplification of the cyclin E (CCNE1) only (to be published elsewhere). The zebrafish GCT reported are more closely related to the Type II seminomas than to Type III spermatocytic seminomas. In contrast, the PUF-8 knock out GCT in $C$. elegans (Subramaniam and Seydoux, 2003) is likely an interesting model for Type III GCTs, i.e., spermatocytic seminomas, as well as those diagnosed in dogs. In this context the specific pattern of mutations found in human spermatocytic seminomas are of inter- est in the canine counterparts (Goriely et al., 2009), as well as recent additional diagnostic markers in humans (Lim et al., 2011). To further put these findings in perspective, the rest of this paper will be related to human Type II GCT, to be referred to as Germ Cell Cancer (GCC).

\section{Epidemiology and risk factors of human GCC}

GCC, predominantly diagnosed in Caucasian males, show an overall increase in incidence, as well as a birth cohort effect in multiple Western European countries (Bergström et al., 1996). Males born during the second World War have a lower incidence, which has been related (partly) to maternal weight (Aschim et al., 2005). This might be related to higher insulin levels, influencing the level of free estrogens (via sex hormone-binding globulin). Both a low and high birth weight is found to be related to the risk of GCC (both infants and adult) (Stephansson et al., 2011). A recent metaanalysis showed that besides birth weight, cryptorchidism, inguinal hernia, twinning, and gestational age are factors influencing the risk of development of GCC (Cook et al., 2009).

No link between human GCC and circulating IGF-1 (IGFBP-3) has been found in a large series of GCC patients and controls (Chia et al., 2008). The main issue here might be that the window of effect, defined by us as the window of sensitization (see below) is not investigated in this study. Analysis at the proper time in development might result in a positive correlation. This is in line with the observation between birth weight and IGF-1 concentration (Joss-Moore et al., 2010). Of special interest is that this has been linked to epigenetic processes, especially in the context of fetal adaptation to a changing environment.

Endocrine dysfunction has been linked to a reduced ano-genital distance (AGD). Indeed, Caucasian boys with hypospadias show this phenomenon (Hsieh et al., 2012). Of interest is that also digit ratios are related to endocrine exposure (Zheng and Cohn, 2011). However, no indication for hormone disruption with this specific read out in relationship with development of GCC has been found so far (Auger and Eustache, 2011). However, such a link was found based on measurements of steroid hormone during early pregnancy (Holl et al., 2009). A disturbed testicular development due to environmental influences, i.e., pro-estrogen and anti-androgen activity (xeno-estrogens), is proposed the mechanistic basis of the so-called Testicular Dysgenesis Syndrome (TDS), as developed and propagated by Niels Skakkebaek (Skakkebaek, 2003). This might result in mild - intermediate - severe forms (hypospadias, cryptorchidism, disturbed fertility, GCC). However, existence of TDS is also questioned (Akre and Richiardi, 2009), including a role for perinatal exposure to estrogens (Ramlau-Hansen et al., 2009).

It is however not a discussion whether particular forms of gonadal disruption, i.e., referred to as DSD, is related to an increased risk of development of a GCC. This has been reviewed in various manuscripts (Cools et al., 2006, Hersmus et al., 2008, Looijenga et al., 2010, Looijenga et al., 2007, Pleskacova et al., 2010). The main risk parameters within this specific group of patients are the following: 1) presence of a specific part of the $Y$ chromosome, referred to as Gonadoblastoma on the $Y$ chromosome (GBY), as originally proposed in 1987 (Page, 1987), in the karyotype of the germ cells; 2) low level of testicularization (i.e., level of testis formation); 3) delayed/blocked maturation of embryonic germ cells and 4) activation of the c-KIT-KITLG pathway (to be further 
discussed in the next paragraphs). In addition, other parameters might influence the risk, like non-scrotal localization of the testis, specific riskalleles, amongst others. These issues will be discussed later as well.

\section{Origin and pathogenesis of human GCC, diagnostic markers}

A number of highly informative diagnostic markers for the earliest developmental stages of GCC pathogenesis has been identified. These predominantly based on knowledge from normal embryogenesis. These include historically alkaline phosphatase (re)activity (Millan and Manes, 1988, Roelofs et al., 1999, Stoop et al., 2011) and the stem cell factor receptor (c-KIT) (Biermann et al., 2007, Meyts et al., 1996, Rajpert-De Meyts and Skakkebæk, 1994, Strohmeyer et al., 1991). Routine use of detection of c-KIT might however result in over-diagnosis as reported recently (Biermann et al., 2012). Activation of the c-KIT pathway has been suggested based on mutation as well genomic amplification studies (Biermann et al., 2007, Looijenga et al., 2003a, Mclntyre et al., 2005a, Mclntyre et al., 2005b, Rapley et al., 2004). In addition, most recently, we demonstrated that ovarian GCC without any sign of DSD have a high frequency of C-KIT mutations, while those with DSD are characterized by presence of GBY, in particularly by expression of Testis Specific Protein on the Y chromosome (TSPY, Hersmus et al., 2012; see below). This dichotomy in pathogenesis between these defined subgroups of patients has been reported before (Hoei-Hansen et al., 2007). This suggests that activation of the c-KIT pathway might be circumvented by the presence of TSPY (to be discussed below).

Of special interest is the finding that early malignant transformed germ cells can be distinguished from delayed matured germ cells based on specific presence of the c-KIT ligand (Stem Cell Factor SCF, also known as KITLG) based on immunohistochemistry (Stoop et al., 2008). This is highly relevant based on the identification of high risk alleles in the general population for development of GCC (see below).

The main contributions to the spectrum of diagnostic markers for GCC based on knowledge of regulatory factors in stem cells is definitely the identification of OCT3/4 (POU5F1) (Looijenga et al., 2003b), as well as SOX2 and SOX17 (De Jong J, 2008., Gopalan et al., 2009, Korkola et al., 2005). This has been supported by many independent studies. While OCT3/4 is consistently found in seminomas and embryonal carcinomas, SOX17 present in the seminomas and SOX2 in the embryonal carcinomas. This allows a straightforward set of transcription factors for the diagnosis of these histological components. This is found to be independent on stage of presentation and pre- versus post-chemotherapy status. Of notion is that SOX17 is related to the embryonic status of hematopoietic stem cells (He et al., 2011, Kim et al., 2007).

The precursor lesion of all seminomas and nonseminomas (embryonal carcinoma, teratoma, yolk sac tumor, and choriocarcinoma) is known as carcinoma in situ of the testis (CIS), as originally proposed in 1972 (Skakkebæk, 1972) and Gonadoblastoma of the dysgenetic gonad reported in 1970 (Scully, 1970). These lesions are both to be identified using OCT3/4. However, they can be distinguished from each other based on characteristics of the supportive cells, being Sertoli cells, stained by SOX9, and Granulosa cells, stained by FOXL2, respectively SCF (Hersmus R, 2008). In fact, the histological composition of the precursor lesion of GCC is determined by the level of testicularization, as defined before. The large amount of epidemiological as well as experimental data indicate that the cell of origin of GCC is a blocked PGC/gonocyte, is in line with expression profiling (Novotny et al., 2012, Sonne et al., 2009), epigenetic status (Eckert et al., 2008, Netto et al., 2008, Werman et al., 2010)as well as the consistent biallelic expression of imprinted genes (Van Gurp et al., 1994, Verkerk et al., 1997), demonstrating their erased pattern of genomic imprinting. In contrast, Type I GCT show a more heterogeneous pattern, supporting the origin of an embryonic stem cells or early (partially erased) embryonic germ cell (Schneider et al., 2001). Moreover, Type III GCT (spermatocytic seminomas) demonstrate a partial paternal pattern of genomic imprinting, in line with a latter stage of germ cell as origin (Sievers et al., 2005), supported by various immunohistochemical staining studies (Lim et al., 2011, Looijenga, 2011). As indicated, TSPY is the main candidate gene within the GBY region, found to be present in the precursor lesions all almost all patients with a GCC, males as well as DSD patients (males and females), with defined exceptions to this rule (see above). A number of relevant characteristics of TSPY will be presented in the next paragraph.

\section{Unique characteristics of Testis Specific Protein on the Y chromosome (TSPY)}

One of the striking observations in the pathogenesis of GB in humans is the fact that only patients with a specific part of the $Y$ chromosome in their karyotype are at risk, referred to as GBY (Page, 1987). Although this genetic fragment contains a number of genes, the most interesting candidate in the development of GCT is TSPY (Testis Specific Protein on the Y chromosome) (Arnemann et al., 1991). It is a multi-copy gene (Manz et al., 1993), expressed in spermatogonia, CIS and GB (Hildenbrand et al., 1999, Kersemaekers et al., 2005, $\mathrm{Ng}$ et al., 2008, Schnieders et al., 1996) It is shown to regulate cell cycle progression, by interacting with cyclin $B_{1}$ (Oram et al., 2006). Of interest is that the level of TSPY in the precursor lesions of GCC correlate with expression level of oncogenes on 12p (Li et al., 2007). In progressed GCC however, TSPY is often lost. In addition, TSPY, besides being multi-copy in nature on the $Y$ chromosome, has various splice variants (Dechend et al., 2000, Vogel and Schmidtke, 1998). No functional mouse homologue has been identified so far (Schubert et al., 2000). Therefore, a transgenetic mouse model was created, in which the human gene integrated in the mouse $Y$ chromosome, and multiplied according to the same level as found in humans (Schubert et al., 2003). Although the protein was generated at the expected time and place (in spermatogonia), the animal model showed no aberrant phenotype, and spermatogenesis was normal. Interestingly in daily clinical routine testicular tissue analysis, immunohistochemical detection of TSPY is informative to visualize presence of germ cells in clinical samples (date not shown).

Most recently it was demonstrated that TSPY might be inhibiting the androgen pathway in human germ cells during development and GCT (Akimoto et al., 2010). This is of specific interest, because it might generate an androgen-insensitivity niche by keeping the androgen receptor in the cytoplasmatic compartment, independently, or on top of its role in cell cycle regulation (see above). These observations need further investigation, in which predomi- 
nantly the presence of the androgen receptor during normal and aberrant germ cell development is an issue of study. However, it might elegantly link the various thoughts about TDS, DSD, c-KIT pathway activation and TSPY in the initial pathogenetic steps of $\mathrm{CIS}$ and GB formation, especially in the context of hypovirilization of patients at increased risk for GCC development.

\section{High throughput approaches (SNP, NGS, methylation)}

A major break through in further understanding the pathogenesis of human GCC came from the two high throughput risk single nucleotide polymorphism (SNP) analyses, one from the USA and one from the UK (Kanetsky et al., 2009, Rapley et al., 2009). A selected number of risk SNPS, preferred to be regarded as susceptibility alleles, were identified, suggested to relate to a common pathway. This included KITLG, DMRT1, SPRY4, and BAK1, all involved in early gonadal development and germ cell survival. Of interest is that Bak1 knock out mice, being a crucial determinant in regulation of germ cell apoptosis, allows visualization of extragonadal, fluorescently tagged PGC (Runyan, 2008). The risk SNPs are in fact the most frequent alleles in the general Caucasian population, although less frequent in distribution in the general Asian and Black populations, as expected related to the incidence of GCC. Additional studies have been published (Turnbull et al., 2010), including description of a single risk SNP within the DMRT1 locus (Kanetsky et al., 2011). These risk SNPS have been found to be independent of the role of cryptorchidism, familial predisposition (Kratz et al., 2011a, Kratz et al., 2011b), as well as spermatogenic function (Ferlin et al., 2012). In addition, gene variants within sex hormone pathways showed significant changes (Kristiansen et al., 2012). Subsequent analysis demonstrated that patients with TDS show specific linkage to defined SNPs (Dalgaard et al., 2012), specifically related to TGFBR3 and BMP7.

\section{miRNAs in the development of germ cells and GCC}

A defined set of non-protein encoding RNAs, referred to microRNAs (miR), are found to be crucial for normal embryonic development and maintenance of an adult individual. In fact, this was originally demonstrated to be relevant in E. elegans (Lee et al., 1993). Moreover, a significant role in development of cancer has been proven in a large number of cases (Esquela-Kerscher and Slack, 2006). miR regulate the transition from mRNA to protein, in which it is expected that around $30 \%$ of all protein encoding genes are under influence of miRs. Profound presence of miR has been reported in embryonic stem cells (Rosa and Brivanlou, 2011). In addition, we reported specific patterns and functions of miRs in GCTs, including both Type II and Type III (Gillis et al., 2007), in line with studies of others, also including Type I (Palmer et al., 2007). The tumor components could be distinguished from each other based on their differentiation status (Gillis et al., 2007). A functional proof for the miR-371-373 cluster was shown in the context of inhibition of down stream target LATS2 of the P53 pathway (Voorhoeve et al., 2006). Interestingly, Lats 2 has also been found to be of importance to overrule cellular senescence. A positive feedback loop between p53 and Lats2 is involved in preventing tetraploidization (Aylon et al., 2006). The fact that it regulates Cdc2 activity in D. melanogaster might be of specific interest (Tao et al., 1999). Most recently, an elegant miR screen has been performed on the precursor lesion of GCC, i.e. CIS, showing similar findings (Novotny et al., 2012). In addition, it is suggested that specific miR are involved in the maturation of mouse gonocytes to pre-spermatogonia (Mclver et al., $2012 a, b)$. Most recently, detection of miR in serum of GCC (adult and pediatric) patients has been reported from two independent groups (Belge et al., 2012, Murray and Coleman, 2012, Palmer et al., 2010). This opens novel possibilities for the diagnosis and follow-up of GCT patients. The impact of miR in the early development of GCT, and their putative clinical implications will be further discussed in the paper by Eini et al. (2013).

\section{Treatment sensitivity and resistance of GCTs and embryonic and adult stem cells}

Overall, GCT, including the Type I and II, can be highly effectively treated using a combination of surgery, irradiation and/or (cisplatinbased) chemotherapy (Horwich et al., 2006). These approaches result in survival of the majority of patients (>90\%), even in case of presence of extensive metastatic disease. However, GCC is the most frequent reason of cancer related death in young Caucasian males. In spite of the overall sensitivity of GCC for the applied treatment strategies, it has become evident that exposure to either irradiation or chemotherapy at young age results in significant side effects at later life, affecting quality of life. These (long term) side effects can include secondary cancers, fatigue, metabolic syndrome, heart and vascular damage and reduced fertility (Hooning et al., 2007, Travis et al., 1997, van den Belt-Dusebout et al., 2007, Van Leeuwen et al., 1993). This strengthens the need for further insights into the sensitivity of GCC and possible resistance. In line with knowledge of undifferentiated verses differentiated cells, the teratomas (both as Type I and II) show the highest resistance to DNA damaging agents. This has been linked to various mechanisms, including DNA repair, export pumps, cell cycle control as well as specific genetic changes, including P53, micro-satellite instability and BRAF (Honecker et al., 2003, Kersemaekers et al., 2002, Koberle et al., 1997, Koberle et al., 1999, Koberle et al., 1996, Koster et al., 2010, Mayer et al., 2002a, Mayer et al., 2003a, Mayer et al., 2002b, Mayer et al., 2001, Mayer et al., 2003b, Spierings et al., 2004). In this context it is interesting that a high proliferation rate is required for cell reprogramming and maintenance of embryonic stem identity (Ruiz et al., 2011). In addition, regulation of $\mathrm{G}_{1}$ arrest determines the sensitivity of embryonic stem cells for DNA damage (induced by irradiation) (Hong and Stambrook, 2004). More relevant aspects in this context are discussed in the papers by Van der Zwan et al. (2013) and Eini et al. (2013).

\section{Window of sensitization (masculinization) of GCC; the genvironment}

The overview provided so far, indicate that there are a number of defined parameters of interest in the early stage development of human GCT, particular GCC. These are related to a window of sensitivity. This matched nicely with the so-called window of masculinization as defined by Philip Sharpe (Welsh et al., 2008). It can be influenced by various other parameters mentioned, like cell cycle regulation (by TSPY or miRNAs), IGF-1 (related to body weight), estrogen-androgen exposure (xeno-estrogens, DSD, TDS), high risk SNPs (affecting regulatory pathways for early gonadal development), and cell signaling by $\mathrm{PTEN}-\mathrm{PI}_{3} \mathrm{~K}$ (pluripotency). 
The data on risk factors for GCC support the model that a particular time and place window is crucial in the earliest development of this type of cancer. Interestingly, this has similarities to the hematopoietic system, in which also KITLG (SCF) seems to be a major player in the field (Perry and Li, 2012). To support this model in more detail, some aspects related to signaling pathways in embryonic germ cells will be discussed in the next paragraph.

\section{Signaling pathways in PGCs and gonocytes}

Identification of the relevant pathways in embryonic germ cells (PGC and gonocytes) is of specific relevance to shed light on the putative disturbance of it in the precursor lesions of human GCC. A number of highly relevant findings has been made during the last years. In all these studies it remains to be shown whether the observations are cross-species in nature. In other words, it remains to be determined whether the data can be interpreted as informative for all models, as well as humans. Mouse PGC (day $11.5-12.5 \mathrm{pc}$ ) are found to express both the estrogen receptor $\alpha$ and $\beta$, and estrogen exposure results in phosphorylation of Akt, Erk and Src, as well as Kit (La Sala et al., 2010). This could be inhibited specifically, which indicates that estrogens act via the nongenomic signaling pathway. Proper balance of $\mathrm{PI}_{3} \mathrm{~K} / \mathrm{Akt}$ is crucial for development of the mouse germ line, preventing dedifferentiation (Kimura et al., 2008). Overactivation results in formation of tumors (teratomas) and embryonic germ cell derivation efficiency. This acts via the p53 pathway, being downstream of $\mathrm{Pl}_{3} \mathrm{~K} / \mathrm{Akt}$. In addition, it is shown that loss of Pten is required for the formation of teratomas (Kimura and Nakano, 2011). The sensitivity window of the Akt signaling is highly restricted, and non-sensitive in the germ cells in mitotic arrest and beginning of meiosis defined (Kimura et al., 2008). Akt activation resulted in phosphorylation of Gsk3, resulting in stabilization of Mdm2, and inhibition of P53, the latter found to be the crucial downstream target.

One of the most intriguing observations is the fact that excess of estrogens during in vitro growth of mouse genital ridges results in induced PGC proliferation (Moe-Behrens et al., 2003). This is due to upregulation of the Kitlg in the somatic cell compartment, resulting in activation of the Kit-pathway via Akt/Pten. The combined estrogen activation, Pten PGC down-regulation and addition of Lif, results in high frequency of transformation of the germ cell population. Bisphenol A (BPA), which has estrogenic activity has been shown to induce proliferation in mouse spermatogonia cell line (GC-1), via activation of Pkg, Egfr/Erk/c-fos (Sheng and Zhu, 2011), associated with ER- $\alpha$ phosphorylation. Besides the role of ER- $\alpha$, also GPR30 was found to be involved.

Knock out of PTEN in human ES resulted in increased selfrenewal, cell survival, and proliferation (Alva et al., 2011). These affected human ES were disrupted in their capacity for differentiation, due to retained OCT3/4 and NANOG expression levels. Interestingly, Pten and P53 have been reported to suppress Nanog expression independently in mouse spermatogonial stem cells (Kuijk et al., 2010). In other words, loss of these markers will result in overexpression of Nanog, and support of undifferentiated stem cells. Interestingly, loss of PTEN protein has been reported consistently in the progression from the pre-invasive to the invasive stage of GCC (Di Vizio et al., 2005). This study also demonstrated the genetic loss as well as inactivation of the PTEN
Modifying parameters

\begin{tabular}{|c|c|}
\hline \multicolumn{2}{|c|}{ (Epi)Genetical } \\
\hline $\begin{array}{l}\text { - (de/hypo)methyl. } \\
\text { - bivalant histones } \\
\text { - erased GI } \\
\text { - GBY (TSPY) }\end{array}$ & $\begin{array}{l}\text { - risk SNPs } \\
\text { - cKIT mutat./ampl. } \\
\text { - AG repeats, ER } \\
\text { - PDE11 }\end{array}$ \\
\hline \multicolumn{2}{|c|}{ (Micro-)Environmental } \\
\hline $\begin{array}{l}\text { - horm. disruptors } \\
\text { - diet }\end{array}$ & $\begin{array}{l}\text { - birth cohort } \\
\text { - migration }\end{array}$ \\
\hline \multicolumn{2}{|c|}{ Clinical-Phenotypical (TDS/DSD) } \\
\hline $\begin{array}{l}\text { - cryptorchidism } \\
\text { - in(sub)fertility } \\
\text { - hypospadias } \\
\text { - inguinal hernia }\end{array}$ & $\begin{array}{l}\text { - fam. predisp. } \\
\text { - birth weight } \\
\text { - maternal weight } \\
\text { - gestational age }\end{array}$ \\
\hline
\end{tabular}

Fig. 1. Schematic representation of the interactive genvironmental model for germ cell cancer (see text for explanation). The required parameters to be fulfilled are underlined.
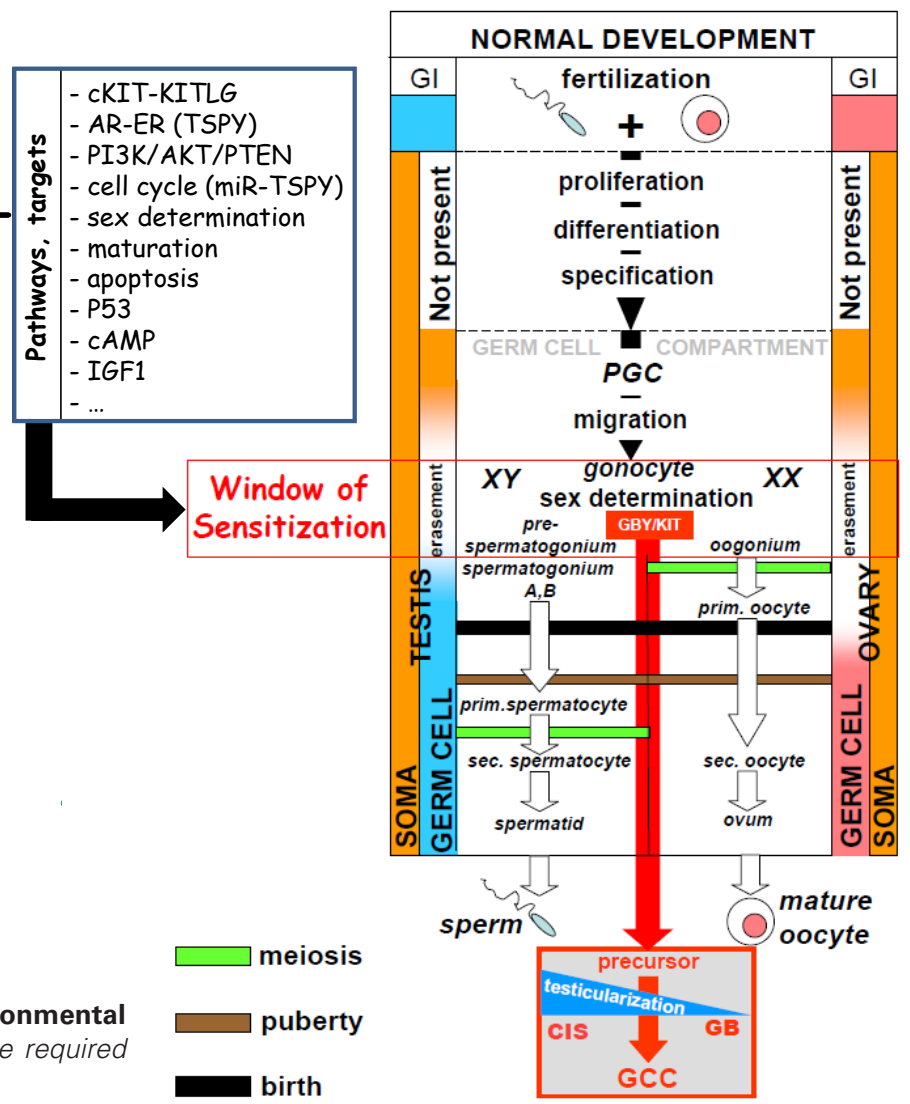
gene in these tumors. Inactivation of PTEN in GCC is supported by an independent analysis (Teng et al., 1997). In addition, this pathway (including p2 $7^{\mathrm{kip} 1}$ ) is crucial for the proliferative activity of NT2 cells, being representative for embryonal carcinoma. In line with this finding AKT signaling has been found in nonseminomatous GCTs (Hennenlotter et al., 2011).

IGF and insulin has been discussed related to the risk of cancer development in general (Gallagher and LeRoith, 2011). IGF-1 receptor is expressed during early human gonadal development, which might be in line with a role of this pathway in this process (Coppola et al., 2009).

To translate these findings to GCC, recent relevant findings of endocrine signaling in GCC will be discussed in the next paragraph.

\section{Endocrine signaling pathways in GCC}

GPR30 has been reported to be present in GCC (Franco et al., 2011). This transmembrane estrogen receptor, which acts parallel to the traditional estrogen pathway, was found by immunohistochemistry to be high in CIS, SE and EC. In addition expression was also found in TCam-2, being the only representative SE cell line so far. However, it must be kept in mind that it is derived from a primary GCC composed of both a SE and EC component. BPA is shown to induce proliferation of TCam-2 cells via the GPER/ GPR30 pathway (Chevalier et al., 2012). Human germ cells only express ER- $\beta$, while reduced in CIS, SE and EC, but high in TE (Esposito et al., 2011). Interestingly, PATZ1 interacts with ER- $\beta$ in normal germ cells, and delocalization is found in SE (with low ER- $\beta$ ). This is regulated by cAMP levels, related to an increased level of nuclear ER- $\beta$, to be inhibited by specific anti-estrogen inhibitors. In addition, an association between specific genetic variants of PDE11 and development GCC has been reported, linked to cAMP signaling via endocrine steroidogenic pathways (Greene et al., 2010, Horvath et al., 2009)

\section{Presentation of the ultimate hypothesis; the model to be tested}

Based on the review of a selected number of observations, an interactive model for the earliest pathogenetic steps in GCC formation is proposed. This relate to a specific window of sensitivity, in parallel with the window of masculinization, being the period of initial maturation of gonocytes to either pre-spermatogonia (in males) and oogonia (in females). Interestingly, this links to the period we refer to as Testicularization. The involved parameters include in principle two levels, being (epi)genetics, including (de)methylation, histone modification, pattern genomic imprinting, GBY, cKIT, SNPS, etc, and (micro)environmental, including hormone disrupters, diet, birth cohort and migration. This will determine clinical-phenotypical (TDS/DSD) characteristics, including cryptorchidism, in(sub)fertility, hypospadias, inguinal hernia etc. These levels interact with each other, and might influence a number of signaling pathways, and processes, including c-KIT-AR-PI3K/AKT/PTEN-P53-CAMP-IGF1, affecting cell cycle control ad sex determination, again organized in a higher order structure of interaction. The bottom line is that subtle changes (pro- and con-) might determine the actual risk for a final blocked maturation of a gonocyte, leading to formation of either CIS of GB at an individual level. The requirements to be fulfilled (underlined in the Fig. 1) include presence of GBY (i.e.,
TSPY), C-KIT activation, and absence of physiological maturation of a gonocyte. An intriguing possible mechanism might be the recently described specific and targeted phosphorylation of the OCT3/4 protein (at position threonine 235), redirecting its function to pluripotency (by interaction with other pluripotency proteins, including NANOG) and loss of its inhibitory effect on the AKT1 promoter, resulting in enhanced resistance to apoptosis (Lin et al., 2012). In addition, it also remains to be demonstrated whether this model is specific for GCC of adolescents and adults, or is also relevant for the (Type I) GCT diagnosed at pediatric age. This interactive genvironmental model directly demonstrates the complexity for proof in a (spontaneous or induced) animal model, or correlation studies in humans. The presence of the potential parameters involved the decision tree for the ultimate transition from a normal to a malignant germ cell must be elucidated in proper clinical and pre-clinical models and studies.

\section{Acknowledgements}

The authors would like to thank all collaborators in the various finalized and continuing studies, as well as all societies for their financial support over the years, and last but not least, all patients that have been willing to participate in the studies performed, resulting in the increasing knowledge about the origin and pathogenesis of this type of cancer.

\section{References}

AKIMOTO, C., UEDA, T., INOUE, K., YAMAOKA, I., SAKARI, M., OBARA, W., FUJIOKA, T., NAGAHARA, A., NONOMURA, N., TSUTSUMI, S. et al., (2010). Testis-specific protein on $Y$ chromosome (TSPY) represses the activity of the androgen receptor in androgen-dependent testicular germ-cell tumors. Proc Natl Acad Sci USA 107: 19891-19896.

AKRE, O. and RICHIARDI, L. (2009). Does a testicular dysgenesis syndrome exist? Hum Reprod 24: 2053-2060.

ALVA, J.A., LEE, G.E., ESCOBAR, E.E. and PYLE, A.D. (2011). Phosphatase and tensin homolog regulates the pluripotent state and lineage fate choice in human embryonic stem cells. Stem Cells 29: 1952-1962.

AMATRUDA, J.F., SHEPARD, J.L., STERN, H.M. and ZON, L.I. (2002). Zebrafish as a cancer model system. Cancer Cell 1: 229-231.

ARNEMANN, J., JAKUBICZKA, S., THURING, S. and SCHMIDTKE, J. (1991). Cloning and sequence analysis of a human Y-chromosome-derived, testicular cDNA, TSPY. Genomics 11: 108-114.

ASCHIM, E.L., GROTMOL, T., TRETLI, S. and HAUGEN, T.B. (2005). Is there an association between maternal weight and the risk of testicular cancer? An epidemiologic study of Norwegian data with emphasis on World War II. Int J Cancer 116: 327-330.

AUGER, J. and EUSTACHE, F. (2011). Second to fourth digit ratios, male genital development and reproductive health: a clinical study among fertile men and testis cancer patients. Int $J$ Androl 34: e49-58.

AYLON, Y., MICHAEL, D., SHMUELI, A., YABUTA, N., NOJIMA, H. and OREN, M. (2006). A positive feedback loop between the p53 and Lats2 tumor suppressors prevents tetraploidization. Genes Dev 20: 2687-2700.

BELGE, G., DIECKMANN, K.P., SPIEKERMANN, M., BALKS, T. and BULLERDIEK, J. (2012). Serum Levels of MicroRNAs miR-371-3: A Novel Class of Serum Biomarkers for Testicular Germ Cell Tumors? Eur Urol. 61: 1068-1069.

BERGSTRÖM, R., ADAMI, H.-O., MOHNER, M., ZATONSKI, W., STORM, H., EKBOM, A., TRETLI, S., TEPPO, L., AKRE, O. and HAKULINEN, T. (1996). Increase in testicular cancer incidence in six European countries: a birth cohort phenomenon. J Natl Cancer Inst 88: 727-733.

BERRY, L.W., WESTLUND, B. and SCHEDL, T. (1997). Germ-line tumor formaton caused by activation of glp-1, a Caerrhabditis elegans member of the Notch family of receptors. Development 124: 925-936.

BIEDERMANN, B., WRIGHT, J., SENFTEN, M., KALCHHAUSER, I., SARATHY, G., LEE, M.H. and CIOSK, R. (2009). Translational repression of cyclin E prevents precocious mitosis and embryonic gene activation during $\mathrm{C}$. elegans meiosis. 
Dev Cell 17: 355-364

BIERMANN, K., GOKE, F., NETTERSHEIM, D., ECKERT, D., ZHOU, H., KAHL, P., GASHAW, I., SCHORLE, H. and BUTTNER, R. (2007). c-KIT is frequently mutated in bilateral germ cell tumours and down-regulated during progression from intratubular germ cell neoplasia to seminoma. J Pathol 213: 311-318.

BIERMANN, K., STOOP, H. and LOOIJENGA, L. (2012). c-KIT protein expression does not discriminate neoplastic from non-neoplastic intratubular germ cells. Histopathology 60: 1017-1019.

BUSH, J.M., GARDINER, D.W., PALMER, J.S., RAJPERT-DE MEYTS, E. and VEERAMACHANENI, D.N. (2011). Testicular germ cell tumours in dogs are predominantly of spermatocytic seminoma type and are frequently associated with somatic cell tumours. Int J Androl 34: e288-295; discussion e295.

CHEVALIER, N., VEGA, A., BOUSKINE, A., SIDDEEK, B., MICHIELS, J.F., CHEVALLIER, D. and FENICHEL, P. (2012). GPR30, the Non-Classical Membrane G Protein Related Estrogen Receptor, Is Overexpressed in Human Seminoma and Promotes Seminoma Cell Proliferation. PLoS One 7: e34672.

CHIA, V.M., QURAISHI, S.M., GRAUBARD, B.I., RUBERTONE, M.V., ERICKSON, R.L., STANCZYK, F.Z. and MCGLYNN, K.A. (2008). Insulin-like growth factor 1, insulin-like growth factor-binding protein 3, and testicular germ-cell tumor risk. Am J Epidemiol 167: 1438-1445.

COOK, M.B., AKRE, O., FORMAN, D., MADIGAN, M.P., RICHIARDI, L. and MCGLYNN, K.A. (2009). A systematic review and meta-analysis of perinatal variables in relation to the risk of testicular cancer--experiences of the mother. Int J Epidemiol 38: 1532-1542.

COOLS, M., DROP, S.L., WOLFFENBUTTEL, K.P., OOSTERHUIS, J.W. and LOOIJENGA, L.H. (2006). Germ cell tumors in the intersex gonad: Old paths, new directions, moving frontiers. Endocr Rev 27: 468-484.

COPPOLA, D., OUBAN, A. and GILBERT-BARNESS, E. (2009). Expression of the insulin-like growth factor receptor 1 during human embryogenesis. Fetal Pediatr Pathol 28: 47-54.

CRITTENDEN, S.L., TROEMEL, E.R., EVANS, T.C. and KIMBLE, J. (1994). GLP-1 is localized to the mitotic region of the C. elegans germ line. Development 120 : 2901-2911.

CUNNINGHAM, J.J., ULBRIGHT, T.M., PERA, M.F. and LOOIJENGA, L.H.J. (2012). Lessons from human teratomas to quide development of safet stem cell therapies. Nature Biotechnology Sept.: 849-857.

DALGAARD, M.D., WEINHOLD, N., EDSGARD, D., SILVER, J.D., PERS, T.H., NIELSEN, J.E., JORGENSEN, N., JUUL, A., GERDS, T.A., GIWERCMAN, A. et al., (2012). A genome-wide association study of men with symptoms of testicular dysgenesis syndrome and its network biology interpretation. JMed Genet49:58-65.

DATTA, M.W., RENSHAW, A.A., DUTTA, A., HOFFMAN, M.A. and LOUGHLIN, K.R. (2000). Evaluation of cyclin expression in testicular germ cell tumors: cyclin $E$ correlates with tumor type, advanced clinical stage, and pulmonary metastasis. Mod Pathol 13: 667-672.

DE JONG J, S.J., GILLIS AJM, VAN GURP RJHLM, VAN DE GEIJN JGM, DE BOER M, HERSMUS R, SAUNDERS PTK, ANDERSON RA, OOSTERHUIS JW, LOOIJENGA LHJ. (2008.). Differential expression of SOX17 and SOX2 in human normal and malignant germ cells and stem cells has biological and clinical implications. J. Pathol. 215: 21-30.

DECHEND, F., WILLIAMS, G., SKAWRAN, B., SCHUBERT, S., KRAWCZAK, M., TYLER-SMITH, C. and SCHMIDTKE, J. (2000). TSPY variants in six loci on the human Y chromosome. Cytogenet Cell Genet 91: 67-71.

DECOTTO, E. and SPRADLING, A.C. (2005). The Drosophila ovarian and testis stem cell niches: similar somatic stem cells and signals. Dev Cell 9: 501-510.

DI VIZIO, D., CITO, L., BOCCIA, A., CHIEFFI, P., INSABATO, L., PETTINATO, G., MOTTI, M.L., SCHEPIS, F., D'AMICO, W., FABIANI, F. et al., (2005). Loss of the tumor suppressor gene PTEN marks the transition from intratubular germ cell neoplasias (ITGCN) to invasive germ cell tumors. Oncogene 10: 1882-1894

ECKERT, D., BIERMANN, K., NETTERSHEIM, D., GILLIS, A.J., STEGER, K., JACK, H.M., MULLER, A.M., LOOIJENGA, L.H. and SCHORLE, H. (2008). Expression of BLIMP1/PRMT5 and concurrent histone $\mathrm{H} 2 \mathrm{~A} / \mathrm{H} 4$ arginine 3 dimethylation in fetal germ cells, CIS/IGCNU and germ cell tumors. BMC Dev Biol 8: 106.

EINI, R., DORSSERS, L.C.J. and LOOIJENGA, L.H.J. (2013). Role of stem cell proteins and microRNAs in embryogenesis and germ cell cancer. Int. J. Dev. Biol. 57: (DOI: 10.1387/ijdb.130020re).

ESPOSITO, F., BOSCIA, F., FRANCO, R., TORNINCASA, M., FUSCO, A., KITAZAWA,
S., LOOIJENGA, L.H. and CHIEFFI, P. (2011). Down-regulation of oestrogen receptor-beta associates with transcriptional co-regulator PATZ1 delocalization in human testicular seminomas. J Pathol 224: 110-120.

ESQUELA-KERSCHER, A. and SLACK, F.J. (2006). Oncomirs - microRNAs with a role in cancer. Nat Rev Cancer 6: 259-269.

ETEMADMOGHADAM, D., DEFAZIO, A., BEROUKHIM, R., MERMEL, C., GEORGE, J., GETZ, G., TOTHILL, R., OKAMOTO, A., RAEDER, M.B., GROUP, A.S. et al., (2009). Integrated Genome-Wide DNA Copy Number and Expression Analysis Identifies Distinct Mechanisms of Primary Chemoresistance in Ovarian Carcinomas. Clin Cancer Res. 15:1417-1427.

FERLIN, A., PENGO, M., PIZZOL, D., CARRARO, U., FRIGO, A.C. and FORESTA, C. (2012). Variants in KITLG predispose to testicular germ cell cancer independently from spermatogenic function. Endocr Relat Cancer 19: 101-108.

FRANCIS, R., BARTON, M.K., KIMBLE, J. and SCHEDL, T. (1995). gld-1, a tumor suppressor gene required for oocyte development in Caenorhabditis elegans. Genetics 139: 579-606.

FRANCO, R., BOSCIA, F., GIGANTINO, V., MARRA, L., ESPOSITO, F., FERRARA, D., PARIANTE, P., BOTTI, G., CARAGLIA, M., MINUCCI, S. et al., (2011). GPR30 is overexpressed in post-puberal testicular germ cell tumors. Cancer Biol Ther 11: 609-613.

GALLAGHER, E.J. and LEROITH, D. (2011). Minireview: IGF, Insulin, and Cancer. Endocrinology 152: 2546-2551.

GILLIS, A.J., STOOP, H.J., HERSMUS, R., OOSTERHUIS, J.W., SUN, Y., CHEN, C., GUENTHER, S., SHERLOCK, J., VELTMAN, I., BAETEN, J. et al., (2007). High-throughput microRNAome analysis in human germ cell tumours. J Pathol 213: 319-328

GONCZY, P., MATUNIS, E. and DINARDO, S. (1997). Bag-of-marbles and benign gonial cell neoplasm act in the germline to restrict proliferation during Drosophila spermatogenesis. Development 124: 4361-4371.

GOPALAN, A., DHALL, D., OLGAC, S., FINE, S.W., KORKOLA, J.E., HOULDSWORTH, J., CHAGANTI, R.S., BOSL, G.J., REUTER, V.E. and TICKOO, S.K. (2009). Testicular mixed germ cell tumors: a morphological and immunohistochemical study using stem cell markers, OCT3/4, SOX2 and GDF3, with emphasis on morphologically difficult-to-classify areas. Mod Pathol. 22: 1066-1074.

GORIELY, A., HANSEN, R.M., TAYLOR, I.B., OLESEN, I.A., JACOBSEN, G.K., MCGOWAN, S.J., PFEIFER, S.P., MCVEAN, G.A., MEYTS, E.R. and WILKIE, A.O. (2009). Activating mutations in FGFR3 and HRAS reveal a shared genetic origin for congenital disorders and testicular tumors. Nat Genet 41: 1247-1251.

GREENE, M.H., KRATZ, C.P., MAI, P.L., MUELLER, C., PETERS, J.A., BRATSLAVSKY, G., LING, A., CHOYKE, P.M., PREMKUMAR, A., BRACCI, J. et al., (2010). Familial testicular germ cell tumors in adults: 2010 summary of genetic risk factors and clinical phenotype. Endocr Relat Cancer 17: R109-R121.

HE, S., KIM, I., LIM, M.S. and MORRISON, S.J. (2011). Sox17 expression confers self-renewal potential and fetal stem cell characteristics upon adult hematopoietic progenitors. Genes Dev 25: 1613-1627.

HEANEY, J.D., LAM, M.Y., MICHELSON, M.V. and NADEAU, J.H. (2008). Loss of the transmembrane but not the soluble kit ligand isoform increases testicular germ cell tumor susceptibility in mice. Cancer Res 68: 5193-5197.

HENNENLOTTER, J., AMEND, B., VOGEL, U., RENNINGER, M., SPRINGER, C., KUEHS, U., STENZL, A. and BEDKE, J. (2011). Differential Akt Signalling in Non-seminomatous Testicular Germ Cell Tumors. Anticancer Res 31:3783-3788.

HERSMUS, R., DE LEEUW, B.H., WOLFFENBUTTEL, K.P., DROP, S.L., OOSTERHUIS, J.W., COOLS, M. and LOOIJENGA, L.H. (2008). New insights into type II germ cell tumor pathogenesis based on studies of patients with various forms of disorders of sex development (DSD). Mol Cell Endocrinol 291: 1-10.

HERSMUS R, K.N., DE LEEUW B, STOOP H, OOSTERHUIS JW, WOLFFENBUTTEL KP, DROP SLS, VEITIA RA, FELLOUS M, JAUBERT F, LOOIJENGA LHJ. (2008). FOXL2 and SOX9 as parameters of female and male gonadal differentiation in patients with various forms of Disorders of Sex Development (DSD). J. Pathol. 215: 31-38.

HERSMUS, R., STOOP, H., VANDE GEIJN, G.J., EINI, R., BIERMANN, K., OOSTERHUIS, J.W., DHOOGE, C., SCHNEIDER, D.T., MEIJSSEN, I.C., DINJENS, W.N. et al., (2012). Prevalence of C-KIT Mutations in Gonadoblastoma and Dysgerminomas of Patients with Disorders of Sex Development (DSD) and Ovarian Dysgerminomas. PLoS One 7: e43952.

HILDENBRAND, R., SCHRODER, W., BRUDE, E., SCHEPLER, A., KONIG, R., 
STUTTE, H.J. and ARNEMANN, J. (1999). Detection of TSPY protein in a unilateral microscopic gonadoblastoma of a Turner mosaic patient with a Y-derived marker chromosome. J Pathol 189: 623-6.

HIME, G.R., LOVELAND, K.L. and ABUD, H.E. (2007). Drosophila spermatogenesis: insights into testicular cancer. Int $J$ Androl 30: 265-274; discussion 274.

HOEI-HANSEN, C.E., KRAGGERUD, S.M., ABELER, V.M., KAERN, J., RAJPERT-DE MEYTS, E. and LOTHE, R.A. (2007). Ovarian dysgerminomas are characterised by frequent KIT mutations and abundant expression of pluripotency markers. Mol Cancer 6: 12.

HOLL, K., LUNDIN, E., SURCEL, H.M., GRANKVIST, K., KOSKELA, P., DILLNER, J., HALLMANS, G., WADELL, G., OLAFSDOTTIR, G.H., OGMUNDSDOTTIR, H.M. et al., (2009). Endogenous steroid hormone levels in early pregnancy and risk of testicular cancer in the offspring: a nested case-referent study. Int $J$ Cancer 124: 2923-2928.

HOLM, T.M., JACKSON-GRUSBY, L., BRAMBRINK, T., YAMADA, Y., RIDEOUT, W.M., 3RD and JAENISCH, R. (2005). Global loss of imprinting leads to widespread tumorigenesis in adult mice. Cancer Cell 8: 275-285.

HONECKER, F., MAYER, F., STOOP, H., OOSTERHUIS, J.W., KOCH, S., BOKEMEYER, C. and LOOIJENGA, L.,.H.J. (2003). Xeroderma pigmentosum group A protein and chemotherapy-resistance in human germ cell tumors. Lab. Invest. 83: 1489-1495.

HONG, Y. and STAMBROOK, P.J. (2004). Restoration of an absent G1 arrest and protection from apoptosis in embryonic stem cells after ionizing radiation. Proc Natl Acad Sci USA 101: 14443-14448.

HOONING, M.J., BOTMA, A., ALEMAN, B.M., BAAIJENS, M.H., BARTELINK, H., KLIJN, J.G., TAYLOR, C.W. and VAN LEEUWEN, F.E. (2007). Long-term risk of cardiovascular disease in 10-year survivors of breast cancer. $J$ Nat/ Cancer Inst 99: 365-375.

HORVATH, A., KORDE, L., GREENE, M.H., LIBE, R., OSORIO, P., FAUCZ, F.R., RAFFIN-SANSON, M.L., TSANG, K.M., DRORI-HERISHANU, L., PATRONAS, Y. et al., (2009). Functional phosphodiesterase $11 \mathrm{~A}$ mutations may modify the risk of familial and bilateral testicular germ cell tumors. Cancer Res 69: 5301-5306.

HORWICH, A., SHIPLEY, J. and HUDDART, R. (2006). Testicular germ-cell cancer. Lancet 367: 754-765.

HSIEH, M.H., EISENBERG, M.L., HITTELMAN, A.B., WILSON, J.M., TASIAN, G.E. and BASKIN, L.S. (2012). Caucasian male infants and boys with hypospadias exhibit reduced anogenital distance. Hum Reprod. 27: 1577-1580.

HSU, H.J., LAFEVER, L. and DRUMMOND-BARBOSA, D. (2008). Diet controls normal and tumorous germline stem cells via insulin-dependent and -independent mechanisms in Drosophila. Dev Biol 313: 700-712.

HUANG, Y.H., CHIN, C.C., HO, H.N., CHOU, C.K., SHEN, C.N., KUO, H.C., WU, T.J., WU, Y.C., HUNG, Y.C., CHANG, C.C. et al., (2009). Pluripotency of mouse spermatogonial stem cells maintained by IGF-1- dependent pathway. FASEB $J$ 23: 2076-2087.

INOUE, M. and WADA, N. (2000). Immunohistochemical detection of p53 and p21 proteins in canine testicular tumours. Vet Rec 146: 370-372.

JAGLARZ, M.K. and HOWARD, K.R. (1994). Primordial germ cell migration in Drosophila Melanogaster is controlled by somatic tissue. Development 120: 83-89.

JEONG, J., VERHEYDEN, J.M. and KIMBLE, J. (2011). Cyclin E and Cdk2 control GLD-1, the mitosis/meiosis decision, and germline stem cells in Caenorhabditis elegans. PLoS Genet 7: e1001348.

JOSS-MOORE, L.A., METCALFE, D.B., ALBERTINE, K.H., MCKNIGHT, R.A. and LANE, R.H. (2010). Epigenetics and fetal adaptation to perinatal events: diversity through fidelity. J Anim Sci 88: E216-E222.

KANETSKY, P.A., MITRA, N., VARDHANABHUTI, S., LI, M., VAUGHN, D.J., LETRERO, R., CIOSEK, S.L., DOODY, D.R., SMITH, L.M., WEAVER, J. et al., (2009). Common variation in KITLG and at 5 q31.3 predisposes to testicular germ cell cancer. Nat Genet 41: 811-815.

KANETSKY, P.A., MITRA, N., VARDHANABHUTI, S., VAUGHN, D.J., LI, M., CIOSEK, S.L., LETRERO, R., D'ANDREA, K., VADDI, M., DOODY, D.R. et al., (2011). A second independent locus within DMRT1 is associated with testicular germ cell tumor susceptibility. Hum Mol Genet 20: 3109-17.

KAWAUCHI, S., YAMAMOTO, Y., UCHIDA, K., CHOCHI, Y., KONDO, T., OGA, A. and SASAKI, K. (2006). Significance of cyclin E and p27 expression in malignant ovarian germ cell tumors: correlation with the cell proliferation activity and clinicopathologic features. Oncol Rep 16: 1029-33.
KEDDE, M., STRASSER, M.J., BOLDAJIPOUR, B., VRIELINK, J.A., SLANCHEV, K., LE SAGE, C., NAGEL, R., VOORHOEVE, P.M., VAN DUIJSE, J., OROM, U.A et al., (2007). RNA-Binding Protein Dnd1 Inhibits MicroRNA Access to Target mRNA. Cell 131: 1273-86.

KERSEMAEKERS, A.M., HONECKER, F., COOLS, M., STOOP, H., MOLIER, M., WOLFFENBUTTEL, K.P., BOKEMEYER, C., LI, Y., LAU, Y.-F.C., OOSTERHUIS, J.W. et al., (2005). Identification of germ cells at risk for neoplastic transformation in gonadoblastomas: An immunohistochemical study for OCT3/4 and TSPY. Hum Pathol 36: 512-521.

KERSEMAEKERS, A.M.F., MAYER, F., MOLIER, M., VAN WEEREN, P.C., OOSTERHUIS, J.W., BOKEMEYER, C. and LOOIJENGA, L.H.J. (2002). Role of P53 and MDM2 in treatment response of human germ cell tumors. J Clin Oncol 20: 1551-1561.

KETTING, R.F. (2007). A Dead End for MicroRNAs. Cell 131: 1226-1227.

KIM, I., SAUNDERS, T.L. and MORRISON, S.J. (2007). Sox17 dependence distinguishes the transcriptional regulation of fetal from adult hematopoietic stem cells. Cell 130: 470-483.

KIMURA, T. and NAKANO, T. (2011). Induction of pluripotency in primordial germ cells. Histol Histopathol 26: 643-650.

KIMURA, T., TOMOOKA, M., YAMANO, N., MURAYAMA, K., MATOBA, S., UMEHARA, H., KANAI, Y. and NAKANO, T. (2008). AKT signaling promotes derivation of embryonic germ cells from primordial germ cells. Development 135: 869-879.

KNOBLICH, J.A., SAUER, K., JONES, L., RICHARDSON, H., SAINT, R. and LEHNER, C.F. (1994). Cyclin E controls S phase progression and its down-regulation during Drosophila embryogenesis is required for the arrest of cell proliferation. Cell 77: 107-120.

KOBERLE, B., GRIMALDI, K.A., SUNTERS, A., HARTLEY, J.A., KELLAND, L.R. and MASTERS, J.R. (1997). DNA repair capacity and cisplatin sensitivity of human testis tumour cells. Int $J$ Cancer 70: 551-555.

KOBERLE, B., MASTERS, J.R., HARTLEY, J.A. and WOOD, R.D. (1999). Defective repair of cisplatin-induced DNA damage caused by reduced XPA protein in testicular germ cell tumours. Curr Biol 9: 273-276.

KOBERLE, B., PAYNE, J., GRIMALDI, K.A., HARTLEY, J.A. and MASTERS, J.R. (1996). DNA repair in cisplatin-sensitive and resistant human cell lines measured in specific genes by quantitative polymerase chain reaction. Biochem Pharmacol 52: 1729-1734.

KORKOLA, J.E., HOULDSWORTH, J., DOBRZYNSKI, D., OLSHEN, A.B., REUTER V.E., BOSL, G.J. and CHAGANTI, R.S. (2005). Gene expression-based classification of nonseminomatous male germ cell tumors. Oncogene 24: 5101-5107.

KOSTER, R., DI PIETRO, A., TIMMER-BOSSCHA, H., GIBCUS, J.H., VAN DEN BERG, A., SUURMEIJER, A.J., BISCHOFF, R., GIETEMA, J.A. and DE JONG, S. (2010). Cytoplasmic p21 expression levels determine cisplatin resistance in human testicular cancer. J Clin Invest 120: 3594-3605.

KRATZ, C.P., GREENE, M.H., BRATSLAVSKY, G. and SHI, J. (2011a). A stratified genetic risk assessment for testicular cancer. Int J Androl 34: e98-e102.

KRATZ, C.P., HAN, S.S., ROSENBERG, P.S., BERNDT, S.I., BURDETT, L., YEAGER, M., KORDE, L.A., MAI, P.L., PFEIFFER, R. and GREENE, M.H. (2011b). Variants in or near KITLG, BAK1, DMRT1, and TERT-CLPTM1L predispose to familial testicular germ cell tumour. J Med Genet 48: 473-476.

KRENTZ AD, M.M., KIM SHINSEOG, COOK MS, CAPEL B, ZHU R, MATIN A, SARVER AL, PARKER KL, GRISWOLD MD, LOOIJENGA LHJ, BARDWELL VJ, ZARKOWER D. (2009). The DM domain protein DMRT1 is a dose-sensitive regulator of fetal germ cell proliferation and pluripotency. Proc. Natl. Acad. Sci. USA 52: 22323-22328.

KRISTIANSEN, W., ANDREASSEN, K.E., KARLSSON, R., ASCHIM, E.L., BREMNES, R.M., DAHL, O., FOSSA, S.D., KLEPP, O., LANGBERG, C.W., SOLBERG, A. et al., (2012). Gene variations in sex hormone pathways and the risk of testicular germ cell tumour: a case-parent triad study in a Norwegian-Swedish population. Hum Reprod. 27: 1525-1535.

KUIJK, E.W., VAN MIL, A., BRINKHOF, B., PENNING, L.C., COLENBRANDER, B. and ROELEN, B.A. (2010). PTEN and TRP53 independently suppress Nanog expression in spermatogonial stem cells. Stem Cells Dev 19: 979-988.

LA SALA, G., FARINI, D. and DE FELICI, M. (2010). Rapid estrogen signalling in mouse primordial germ cells. Exp Cell Res 316: 1716-1727.

LEE, J., KANATSU-SHINOHARA, M., MORIMOTO, H., KAZUKI, Y., TAKASHIMA, S., OSHIMURA, M., TOYOKUNI, S. and SHINOHARA, T. (2009). Genetic recon- 
struction of mouse spermatogonial stem cell self-renewal in vitro by Ras-cyclin D2 activation. Cell Stem Cell 5: 76-86.

LEE, R.C., FEINBAUM, R.L. and AMBROS, V. (1993). The C. elegans heterochronic gene lin-4 encodes small RNAs with antisense complementarity to lin-14. Cell 75: 843-854.

LI, Y., TABATABAI, Z.L., LEE, T.L., HATAKEYAMA, S., OHYAMA, C., CHAN, W.Y., LOOIJENGA, L.H. and LAU, Y.F. (2007). The Y-encoded TSPY protein: a significant marker potentially plays a role in the pathogenesis of testicular germ cell tumors. Hum Pathol 38: 1470-1481.

LIBERAL, V., DE MIGUEL, M.P., HENZE, M., NISTAL, M. and REED, S.I. (2010). Reduced spermatogonial proliferation and decreased fertility in mice overexpressing cyclin $\mathrm{E}$ in spermatogonia. Cell Cycle 9: 4222-4227.

LIM, J., GORIELY, A., TURNER, G., EWEN, K., JACOBSEN, G., GRAEM, N., WILKIE, A. and RAJPERT-DE MEYTS, E. (2011). OCT2, SSX and SAGE1 reveal the phenotypic hetereogeneity of spermatocytic seminoma reflecting distinct subpopulations of spermatogonia. J. Pathol 224: 473-483.

LIN, Y., YANG, Y., LI, W., CHEN, Q., LI, J., PAN, X., ZHOU, L., LIU, C., CHEN, C., HE, J. et al., (2012). Reciprocal regulation of akt and oct4 promotes the self-renewal and survival of embryonal carcinoma cells. Mol Cell 48: 627-40.

LINGER, R., DUDAKIA, D., HUDDART, R., TUCKER, K., FRIEDLANDER, M., PHILLIPS, K.A., HOGG, D., JEWETT, M.A., LOHYNSKA, R., DAUGAARD, G. et al., (2008). Analysis of the DND1 gene in men with sporadic and familial testicular germ cell tumors. Genes Chromosomes Cancer 47: 247-252.

LOOIJENGA, L.H. (2011). Spermatocytic seminoma: toward further understanding of pathogenesis. J Pathol 224: 431-433.

LOOIJENGA, L.H., HERSMUS, R., DE LEEUW, B.H., STOOP, H., COOLS, M., OOSTERHUIS, J.W., DROP, S.L. and WOLFFENBUTTEL, K.P. (2010). Gonadal tumours and DSD. Best Pract Res Clin Endocrinol Metab 24: 291-310.

LOOIJENGA, L.H., HERSMUS, R., OOSTERHUIS, J.W., COOLS, M., DROP, S.L. and WOLFFENBUTTEL, K.P. (2007). Tumor risk in disorders of sex development (DSD). Best Pract Res Clin Endocrinol Metab 21: 480-495.

LOOIJENGA, L.H., VERKERK, A.J., DEKKER, M.C., VAN GURP, R.J., GILLIS, A.J. and OOSTERHUIS, J.W. (1998). Genomic imprinting in testicular germ cell tumours. Apmis 106: 187-95; discussion 196-197.

LOOIJENGA, L.H.J., DE LEEUW, P.J.C., VAN OORSCHOT, M., VAN GURP, R.J.H.L.M., STOOP, H., GILLIS, A.J.M., DE GOUVEIA BRAZAO, C.A., WEBER, A., KIRKELS, W.J., VAN DIJK, T. et al., (2003a). Stem cell factor receptor (c-KIT) codon 816 mutations predict development of bilateral testicular germ cell tumors. Cancer Res 63: 7674-7678

LOOIJENGA, L.H.J., OLIE, R.A., VAN DER GAAG, I., VAN SLUIJS, F.J., MATOSKA, J., PLOEM-ZAAIJER, J., KNEPFLE, C. and OOSTERHUIS, J.W. (1994). Seminomas of the canine testis; counterpart of spermatocytic seminoma of men? Lab Invest 71: 490-496.

LOOIJENGA, L.H.J., OOSTERHUIS J.W. (1999). Pathogenesis of testicular germ cell tumors. Rev of Reproduction 4: 90-100.

LOOIJENGA, L.H.J., STOOP, H., DE LEEUW, P.J.C., DE GOUVEIA BRAZAO, C.A., GILLIS, A.J.M., VAN ROOZENDAAL, K.E.P., VAN ZOELEN, E.J.J., WEBER, R.F.A., WOLFFENBUTTEL, K.P., VAN DEKKEN, H. et al., (2003b). POU5F1 (OCT3/4) identifies cells with pluripotent potential in human germ cell tumors. Cancer Res 63: 2244-2250.

MANZ, E., SCHNIEDERS, F., BRECHLIN, A.M. and SCHMIDTKE, J. (1993). TSPYrelated sequences represent a microheterogeneous gene family organized as constitutive elements in DYZ5 tandem repeat units on the human Y chromosome. Genomics 17: 726-731.

MATSON, C.K., MURPHY, M.W., SARVER, A.L., GRISWOLD, M.D., BARDWELL, V.J. and ZARKOWER, D. (2011). DMRT1 prevents female reprogramming in the postnatal mammalian testis. Nature 476: 101-104.

MATSON, C.K. and ZARKOWER, D. (2012). Sex and the singular DM domain: insights into sexual regulation, evolution and plasticity. Nat Rev Genet 13: 163-174.

MAYER, F., GILLIS, A.J.M., DINJENS, W., OOSTERHUIS, J.W., BOKEMEYER, C. and LOOIJENGA, L.H.J. (2002a). Microsatellite instability of germ cell tumors is associated with resistance to systemic treatement. Cancer Res 62: 2758-2760.

MAYER, F., HONECKER, F., LOOIJENGA, L.H.J. and BOKEMEYER, C. (2003a). Towards understanding the biological basis of the response to cisplatin-based chemotherapy in germ cell tumors. Ann Oncol 9: 825-832.

MAYER, F., KERSEMAEKERS, A.M., OOSTERHUIS, J.W., BOKEMEYER, C. and
LOOIJENGA, L.,.H.J. (2002b). p53 and MDM2 in germ cell cancer treatment response. J Clin Oncol 20: 1551-1561.

MAYER, F., STOOP, H., KOLLMANSBERGER, C., OOSTERHUIS, J.W., BOKEMEYER, C. and LOOIJENGA, L.H.J. (2001). Positivity for xeroderma pigmentosa protein $A(X P A)$ in unselected and cisplatin-resistant germ cell tumors (GCT). $J$ Clin Oncol 20: 121a.

MAYER, F., STOOP, H., SCHEFFER, G.L., SCHEPER, R., OOSTERHUIS, J.W., LOOIJENGA, L.H. and BOKEMEYER, C. (2003b). Molecular determinants of treatment response in human germ cell tumors. Clin Cancer Res 9: 767-773.

MCINTYRE, A., SUMMERSGILL, B., GRYGALEWICZ, B., GILLIS, A.J., STOOP, J., VAN GURP, R.J., DENNIS, N., FISHER, C., HUDDART, R., COOPER, C. et al., (2005a). Amplification and overexpression of the KIT gene is associated with progression in the seminoma subtype of testicular germ cell tumors of adolescents and adults. Cancer Res 65: 8085-8089.

MCINTYRE, A., SUMMERSGILL, B., SPENDLOVE, H.E., HUDDART, R., HOULSTON R. and SHIPLEY, J. (2005b). Activating mutations and/or expression levels of tyrosine kinase receptors GRB7, RAS, and BRAF in testicular germ cell tumors. Neoplasia 7: 1047-1052.

MCIVER, S.C., ROMAN, S.D., NIXON, B. and MCLAUGHLIN, E.A. (2012a). miRNA and mammalian male germ cells. Hum Reprod Update. 18: 44-59.

MCIVER, S.C., STANGER, S.J., SANTARELLI, D.M., ROMAN, S.D., NIXON, B. and MCLAUGHLIN, E.A. (2012b). A Unique Combination of Male Germ Cell miRNAs Coordinates Gonocyte Differentiation. PLoS One 7: e35553.

MEYTS, E.R., JORGENSEN, N., MULLER, J. and SKAKKEBAEK, N.E. (1996). Prolonged expression of the c-kit receptor in germ cells of intersex fetal testes. J Pathol 178: 166-169.

MILLAN, J.L. and MANES, T. (1988). Seminoma-derived Nagao isozyme is encoded by a germ-cell alkaline phosphatase gene. PNAS 1985: 3024-3028.

MOE-BEHRENS, G.H., KLINGER, F.G., ESKILD, W., GROTMOL, T., HAUGEN, T.B. and DE FELICI, M. (2003). Akt/PTEN signaling mediates estrogen-dependent proliferation of primordial germ cells in vitro. Mol Endocrinol 17: 2630-2638.

MURAKAMI, Y., TATEYAMA, S., UCHIDA, K. and YAMAGUCHI, R. (2001). Immunohistochemical analysis of cyclins in canine normal testes and testicular tumors. $J$ Vet Med Sci 63: 909-912.

MURRAY, M.J. and COLEMAN, N. (2012). Testicular cancer: A new generation of biomarkers for malignant germ cell tumours. Nat Rev Urol. 9: 298-300.

NAKAYAMA, K., NAGAHAMA, H., MINAMISHIMA, Y.A., MATSUMOTO, M., NAKAMICHI, I., KITAGAWA, K., SHIRANE, M., TSUNEMATSU, R., TSUKIYAMA, T., ISHIDA, N. et al., (2000). Targeted disruption of Skp2 results in accumulation of cyclin E and p27(Kip1), polyploidy and centrosome overduplication. EMBO J 19: 2069-20681.

NARBONNE, P. and ROY, R. (2006). Inhibition of germline proliferation during C. elegans dauer development requires PTEN, LKB1 and AMPK signalling. Development 133: 611-619.

NELSON, V.R., HEANEY, J.D., TESAR, P.J., DAVIDSON, N.O. and NADEAU, J.H (2012). Transgenerational epigenetic effects of the Apobec1 cytidine deaminase deficiency on testicular germ cell tumor susceptibility and embryonic viability. Proc Natl Acad Sci USA 109: 2766-2773.

NETTO, G.J., NAKAI, Y., NAKAYAMA, M., JADALLAH, S., TOUBAJI, A., NONOMURA, N., ALBADINE, R., HICKS, J.L., EPSTEIN, J.I., YEGNASUBRAMANIAN, S. et al., (2008). Global DNA hypomethylation in intratubular germ cell neoplasia and seminoma, but not in nonseminomatous male germ cell tumors. Mod Pathol 21 1337-11344.

NEUMANN, J.C., CHANDLER, G.L., DAMOULIS, V.A., FUSTINO, N.J., LILLARD K., LOOIJENGA, L., MARGRAF, L., RAKHEJA, D. and AMATRUDA, J.F. (2011a). Mutation in the type IB bone morphogenetic protein receptor Alk6b impairs germcell differentiation and causes germ-cell tumors in zebrafish. Proc Natl Acad Sci USA 108: 13153-13158

NEUMANN, J.C., LILLARD, K., DAMOULIS, V. and AMATRUDA, J.F. (2011b). Zebrafish models of germ cell tumor. Methods Cell Biol 105: 3-24.

NG, S.B., YONG, M.H., KNIGHT, L.A., LEE, V.K., NADARAJAH, S., STOOP, H. and LOOIJENGA, L.H. (2008). Gonadoblastoma-associated mixed germ cell tumour in 46,XY complete gonadal dysgenesis (Swyer syndrome): analysis of Y chromosomal genotype and OCT3/4 and TSPY expression profile. Histopathology 52: 644-646.

NOVOTNY, G.W., BELLING, K.C., BRAMSEN, J.B., NIELSEN, J.E., BORK-JENSEN, J., ALMSTRUP, K., SONNE, S.B., KJEMS, J., RAJPERT-DE MEYTS, E. and 
LEFFERS, H. (2012). MicroRNA expression profiling of carcinoma in situ cells of the testis. Endocr Relat Cancer 19: 365-379.

ORAM, S.W., LIU, X.X., LEE, T.L., CHAN, W.Y. and LAU, Y.F. (2006). TSPY potentiates cell proliferation and tumorigenesis by promoting cell cycle progression in HeLa and NIH3T3 cells. BMC Cancer 6: 154.

PAGE, D.C. (1987). Hypothesis: a Y-chromosomal gene causes gonadoblastoma in dysgenetic gonads. Development 101(Suppl): 151-155.

PALMER, R.D., FOSTER, N.A., VOWLER, S.L., ROBERTS, I., THORNTON, C.M., HALE, J.P., SCHNEIDER, D.T., NICHOLSON, J.C. and COLEMAN, N. (2007). Malignant germ cell tumours of childhood: new associations of genomic imbalance. Br J Cancer 96: 667-676.

PALMER, R.D., MURRAY, M.J., SAINI, H.K., VANDONGEN, S., ABREU-GOODGER, C., MURALIDHAR, B., PETT, M.R., THORNTON, C.M., NICHOLSON, J.C., ENRIGHT, A.J. et al., (2010). Malignant germ cell tumors display common microRNA profiles resulting in global changes in expression of messenger RNA targets. Cancer Res 70: 2911-2923.

PARISI, T., BECK, A.R., ROUGIER, N., MCNEIL, T., LUCIAN, L., WERB, Z. and AMATI, B. (2003). Cyclins E1 and E2 are required for endoreplication in placental trophoblast giant cells. EMBO J 22: 4794-4803.

PERRY, J.M. and LI, L. (2012). To be or not to be a stem cell: dissection of cellular and molecular components of haematopoietic stem cell niches. EMBOJ31:1060-1061.

PLESKACOVA, J., HERSMUS, R., OOSTERHUIS, J.W., SETYAWATI, B.A., FARADZ, S.M., COOLS, M., WOLFFENBUTTEL, K.P., LEBL, J., DROP, S.L. and LOOIJENGA, L.H. (2010). Tumor Risk in Disorders of Sex Development. Sex Dev 4: 259-269.

RAJPERT-DE MEYTS, E. and SKAKKEB/EK, N.E. (1994). Expression of the c-kit protein product in carcinoma-in-situ and invasive testicular germ cell tumours. Int J Androl 17: 85-92.

RAMLAU-HANSEN, C.H., OLESEN, A.V., PARNER, E.T., SORENSEN, H.T. and OLSEN, J. (2009). Perinatal markers of estrogen exposure and risk of testicular cancer: follow-up of 1,333,873 Danish males born between 1950 and 2002. Cancer Causes Control 20: 1587-1592.

RAPLEY, E.A., HOCKLEY, S., WARREN, W., JOHNSON, L., HUDDART, R., CROCKFORD, G., FORMAN, D., LEAHY, M.G., OLIVER, D.T., TUCKER, K. et al., (2004). Somatic mutations of KIT in familial testicular germ cell tumours. $\mathrm{Br}$ J Cancer 90: 2397-2401.

RAPLEY, E.A., TURNBULL, C., AL OLAMA, A.A., DERMITZAKIS, E.T., LINGER, R., HUDDART, R.A., RENWICK, A., HUGHES, D., HINES, S., SEAL, S. et al., (2009). A genome-wide association study of testicular germ cell tumor. Nat Genet 41: 807-810.

RAYMOND, C.S., MURPHY, M.W., O'SULLIVAN, M.G., BARDWELL, V.J. and ZARKOWER, D. (2000). Dmrt1, a gene related to worm and fly sexual regulators, is required for mammalian testis differentiation [In Process Citation]. Genes Dev 14: 2587-2595

ROELOFS, H., MANES, T., MILLAN, J.L., OOSTERHUIS, J.W. and LOOIJENGA, L.H.J. (1999). Heterogeneity in alkaline phosphatase isozyme expression in human testicular germ cell tumors. An enzyme-/immunohistochemical and molecular analysis. J Pathol 189: 236-244.

ROSA, A. and BRIVANLOU, A.H. (2011). A regulatory circuitry comprised of miR-302 and the transcription factors $\mathrm{OCT} 4$ and NR2F2 regulates human embryonic stem cell differentiation. EMBO J 30: 237-248.

RUIZ, S., PANOPOULOS, A.D., HERRERIAS, A., BISSIG, K.D., LUTZ, M., BERGGREN, W.T., VERMA, I.M. and IZPISUABELMONTE, J.C. (2011). A high proliferation rate is required for cell reprogramming and maintenance of human embryonic stem cell identity. Curr Biol 21: 45-52.

RUNYAN, C., GU Y, SHOEMAKER A, LOOIJENGA LHJ, WYLIE C. (2008). The distribution and behavior of extragonadal primordial germ cells in Bax mutant mice suggest a novel origin for sacrococcygeal germ cell tumors. Int. J. Dev. Biol. 52: 333-344.

RUNYAN, C., SCHAIBLE, K., MOLYNEAUX, K., WANG, Z., LEVIN, L. and WYLIE, C. (2006). Steel factor controls midline cell death of primordial germ cells and is essential for their normal proliferation and migration. Development 133:4861-4869.

SCHLOTTHAUER, C.F. (1938). Testicular tumor in dogs. Journal.of.Urology. 40: 539-550.

SCHNEIDER, D.T., SCHUSTER, A.E., FRITSCH, M.K., HU, J., OLSON, T., LAUER, S., GOBEL, U. and PERLMAN, E.J. (2001). Multipoint imprinting analysis indicates a common precursor cell for gonadal and nongonadal pediatric germ cell tumors. Cancer Res 61: 7268-7276.

SCHNIEDERS, F., DORK, T., ARNEMANN, J., VOGEL, T., WERNER, M. and SCHMIDTKE, J. (1996). Testis-specific protein, Y-encoded (TSPY) expression in testicular tissues. Hum Mol Genet 5: 1801-1807.

SCHUBERT, S., DECHEND, F., SKAWRAN, B., KRAWCZAK, M. and SCHMIDTKE, J. (2000). Molecular evolution of the murine tspy genes. Cytogenet Cell Genet 91: 239-242

SCHUBERT, S., SKAWRAN, B., DECHEND, F., NAYERNIA, K., MEINHARDT, A., NANDA, I., SCHMID, M., ENGEL, W. and SCHMIDTKE, J. (2003). Generation and characterization of a transgenic mouse with a functional human TSPY. Biol Reprod 69: 968-75.

SCULLY, R.E. (1970). Gonadoblastoma/Areview of 74 cases. Cancer25: 1340-1356.

SCULLY, R.E. and COFFIN, D.L. (1961). Canine testicular tumors, with specia references to their histogenesis, comparative morphology, and endocrinology. Cancer 5: 788

SHENG, Z.G. and ZHU, B.Z. (2011). Low concentrations of bisphenol Ainduce mouse spermatogonial cell proliferation by $G$ protein-coupled receptor 30 and estrogen receptor-alpha. Environ Health Perspect 119: 1775-1780.

SIEVERS, S., ALEMAZKOUR, K., ZAHN, S., PERLMAN, E.J., GILLIS, A.J., LOOIJENGA, L.H., GOBEL, U. and SCHNEIDER, D.T. (2005). IGF2/H19 imprinting analysis of human germ cell tumors (GCTs) using the methylation-sensitive singlenucleotide primer extension method reflects the origin of GCTs in different stages of primordial germ cell development. Genes Chromosomes Cancer 44: 256-264.

SKAKKEB/EK, N.E. (1972). Possible carcinoma-in-situ of the testis. Lancet516-517. SKAKKEBAEK, N.E. (2003). Testicular dysgenesis syndrome. Horm Res60 Suppl3:49. SONNE, S.B., ALMSTRUP, K., DALGAARD, M., JUNCKER, A.S., EDSGARD, D., RUBAN, L., HARRISON, N.J., SCHWAGER, C., ABDOLLAHI, A., HUBER, P.E. et al., (2009). Analysis of gene expression profiles of microdissected cell populations indicates that testicular carcinoma in situ is an arrested gonocyte. Cancer Res 69: 5241-5250.

SPIERINGS, D.C., DE VRIES, E.G., STEL, A.J., TE RIETSTAP, N., VELLENGA, E. and DE JONG, S. (2004). Low p21Waf1/Cip1 protein level sensitizes testicular germ cell tumor cells to Fas-mediated apoptosis. Oncogene 23: 4862-4872.

SPILLER, C.M., FENG, C.-W., JACKSON, A., GILLIS, A.J.M., ROLLAND, A.D., LOOIJENGA, L.H.J., KOOPMAN, P. and BOWLES, J. (2012). Endogenous Nodal signalling regulates germ cell potency during mammalian testis development. Development 139: 4123-4132.

SPRADLING, A., FULLER, M.T., BRAUN, R.E. and YOSHIDA, S. (2011). Germline stem cells. Cold Spring Harb Perspect Biol 3: a002642.

SRINIVASAN, S., MAHOWALD, A.P. and FULLER, M.T. (2012). The receptor tyrosine phosphatase Lar regulates adhesion between Drosophila male germline stem cells and the niche. Development 139: 1381-1390.

STEPHANSSON, O., WAHNSTROM, C., PETTERSSON, A., SORENSEN, H.T., TRETLI, S., GISSLER, M., TROISI, R., AKRE, O. and GROTMOL, T. (2011). Perinatal risk factors for childhood testicular germ-cell cancer: a Nordic populationbased study. Cancer Epidemiol 35: e100-e104.

STEVENS, L.C. (1970). The development of transplantable teratocarcinomas from intratesticular grafts of pre- and postimplantation mouse embryos. Dev Biol 21 364-382.

STEVENS, L.C. and VARNUM, D.S. (1974). The development of teratomas from parthenogenetically activated ovarian mouse eggs. Developmental Biology 37 369-380

STOOP, H., HONECKER, F., VAN DE GEIJN, G., GILLIS, A., COOLS, M., DE BOER, M., BOKEMEYER, C., WOLFFENBUTTEL, K., DROP, S., DE KRIJGER, R. et al., (2008). Stem cell factor as a novel diagnostic marker for early malignant germ cells. J Pathol 216: 43-54.

STOOP, H., KIRKELS, W., DOHLE, G.R., GILLIS, A.J., DEN BAKKER, M.A. BIERMANN, K., OOSTERHUIS, W. and LOOIJENGA, L.H. (2011). Diagnosis of testicular carcinoma in situ '(intratubular and microinvasive)' seminoma and embryonal carcinoma using direct enzymatic alkaline phosphatase reactivity on frozen histological sections. Histopathology 58: 440-446.

STROHMEYER, T., PETER, S., HARTMANN, M., MUNEMITSU, S., ACKERMANN, R., ULLRICH, A. and SLAMON, D.J. (1991). Expression of the hst-1 and c-kit protooncogenes in human testicular germ cell tumors. Cancer Res 51: 1811-1816. SUBRAMANIAM, K. and SEYDOUX, G. (2003). Dedifferentiation of Primary Sper- 
matocytes into Germ Cell Tumors in C. elegans Lacking the Pumilio-like Protein PUF-8. Curr Biol 13: 134-139.

TAO, W., ZHANG, S., TURENCHALK, G.S., STEWART, R.A., ST. JOHN, M.A., CHEN W. and XU, T. (1999). Human homologue of the Drosophila Melanogaster lats tumour suppressor modulates CDC2 activity. Nat Genet 21: 177-181.

TENG, D.H., HU, R., LIN, H., DAVIS, T., ILIEV, D., FRYE, C., SWEDLUND, B., HANSEN, K.L., VINSON, V.L., GUMPPER, K.L. etal., (1997). MMAC1/PTEN mutations in primary tumor specimens and tumor cell lines. Cancer Res 57: 5221-5225.

TRAN, J., BRENNER, T.J. and DINARDO, S. (2000). Somatic control over the germline stem cell lineage during Drosophila spermatogenesis [In Process Citation]. Nature 407: 754-757.

TRAVIS, L.B., CURTIS, R.E., STORM, H., HALL, P., HOLOWATY, E., VAN LEEUWEN, F.E., KOHLER, B.A., PUKKALA, E., LYNCH, C.F., ANDERSSON, M. et al., (1997). Risk of second malignant neoplasms among long-term survivors of testicular cancer [see comments]. J Natl Cancer Inst 89: 1429-1439.

TURNBULL, C., RAPLEY, E.A., SEAL, S., PERNET, D., RENWICK, A., HUGHES, D., RICKETTS, M., LINGER, R., NSENGIMANA, J., DELOUKAS, P. et al., (2010). Variants near DMRT1, TERT and ATF7IP are associated with testicular germ cell cancer. Nat Genet. 42: 604-607.

UHLENHAUT, N.H., JAKOB, S., ANLAG, K., EISENBERGER, T., SEKIDO, R., KRESS, J., TREIER, A.C., KLUGMANN, C., KLASEN, C., HOLTER, N.I. et al., (2009). Somatic sex reprogramming of adult ovaries to testes by FOXL2 ablation. Cell 139: 1130-1142.

UHLENHAUT, N.H. and TREIER, M. (2006). Foxl2 function in ovarian development. Mol Genet Metab 88: 225-234.

VAN DEN BELT-DUSEBOUT, A.W., DE WIT, R., GIETEMA, J.A., HORENBLAS, S., LOUWMAN, M.W., RIBOT, J.G., HOEKSTRA, H.J., OUWENS, G.M., ALEMAN, B.M. and VAN LEEUWEN, F.E. (2007). Treatment-specific risks of second malignancies and cardiovascular disease in 5-year survivors of testicular cancer. $J$ Clin Oncol 25: 4370-4378.

VAN DER ZWAN, Y.G., STOOP, H. ROSSELLO, F., WHITE, S.J. and LOOIJENGA, L.H.J. (2013). Role of epigenetics in the etiology of germ cell cancer. Int. J. Dev. Biol. 57: (doi: 10.1387/ijdb.130017II).

VAN GURP, R.J.L.M., OOSTERHUIS, J.W., KALSCHEUER, V., MARIMAN, E.C.M. and LOOIJENGA, L.H.J. (1994). Human testicular germ cell tumors show biallelic expression of the H19 and IGF2 gene. J Natl Cancer Inst 86: 1070-1075.

VAN LEEUWEN, F.E., STIGGELBOUT, A.M., VAN DEN BELT-DUSEBOUT, A.W., NOYON, R., ELIEL, M.R., VAN KERKHOFF, E.H.M., DELEMARRE, J.F.M. and SOMERS, R. (1993). Second cancer risk following testicular cancer: A follow-up study of 1,909 patients. J. Clin Oncol 11: 415-424.
VERKERK, A.J., ARIEL, I., DEKKER, M.C., SCHNEIDER, T., VAN GURP, R.J., DE GROOT, N., GILLIS, A.J., OOSTERHUIS, J.W., HOCHBERG, A.A. and LOOIJENGA, L.H. (1997). Unique expression patterns of H19 in human testicular cancers of different etiology. Oncogene 14: 95-107.

VOGEL, T. and SCHMIDTKE, J. (1998). Structure and function of TSPY, the Ychromosome gene coding for the "testis-specific protein". Cytogenet Cell Genet 80: $209-213$.

VOORHOEVE, P.M., LE SAGE, C., SCHRIER, M., GILLIS, A.J., STOOP, H., NAGEL, R., LIU, Y.P., VAN DUIJSE, J., DROST, J., GRIEKSPOOR, A. et al., (2006). A genetic screen implicates miRNA-372 and miRNA-373 as oncogenes in testicular germ cell tumors. Cell 124: 1169-1181.

WALT, H., OOSTERHUIS, J.W. and STEVENS, L.C. (1993). Experimental testicular germ cell tumorigenesis in mouse strains with and without spontaneous tumours differs from development of germ cell tumours of the adult human testis. Int $J$ Androl 16: 267-271.

WELSH, M., SAUNDERS, P.T., FISKEN, M., SCOTT, H.M., HUTCHISON, G.R., SMITH L.B. and SHARPE, R.M. (2008). Identification in rats of a programming window for reproductive tract masculinization, disruption of which leads to hypospadias and cryptorchidism. J Clin Invest 118: 1479-1490.

WERMAN, H., STOOP, H., GILLIS, A.J., HONECKER, F., VAN GURP, R.J., AMMERPOHL, O., RICHTER, J., OOSTERHUIS, J.W., BOKEMEYER, C. and LOOIJENGA, L.H. (2010). Global DNA methylation in fetal human germ cells and germ cell tumours: association with differentiation and cisplatin resistance. J Pathol 221: 433-442.

WESTERMAN, B.A., BRAAT, A.K., TAUB, N., POTMAN, M., VISSERS, J.H., BLOM, M., VERHOEVEN, E., STOOP, H., GILLIS, A., VELDS, A. et al., (2011). Agenomewide RNAi screen in mouse embryonic stem cells identifies Mp1 as a key mediator of differentiation. J Exp Med 208: 2675-2689.

WESTERN, P.S., MILES, D.C., VAN DEN BERGEN, J.A., BURTON, M. and SINCLAIR, A.H. (2008). Dynamic regulation of mitotic arrest in fetal male germ cells. Stem Cells 26: 339-347.

WYLIE, C. (1999). Germ cells. Cell 96: 165-174.

YOUNGREN, K.K., COVENEY, D., PENG, X., BHATTACHARYA, C., SCHMIDT, L.S., NICKERSON, M.L., LAMB, B.T., DENG, J.M., BEHRINGER, R.R., CAPEL, B. et al., (2005). The Ter mutation in the dead end gene causes germ cell loss and testicular germ cell tumours. Nature 435: 360-364.

YU, C.H., HWANG, D.N., YHEE, J.Y., KIM, J.H., IM, K.S., NHO, W.G., LYOO, Y.S and SUR, J.H. (2009). Comparative immunohistochemical characterization of canine seminomas and Sertoli cell tumors. J Vet Sci 10: 1-7.

ZHENG, Z. and COHN, M.J. (2011). Developmental basis of sexually dimorphic digit ratios. Proc Natl Acad Sci USA 108: 16289-16294. 


\section{Further Related Reading, published previously in the Int. J. Dev. Biol.}

Germline stem cells and sex determination in Hydra

Chiemi Nishimiya-Fujisawa and Satoru Kobayashi

Int. J. Dev. Biol. (2012) 56: 499-508

Impaired meiotic competence in putative primordial germ cells produced from mouse embryonic stem cells Marianna Tedesco, Donatella Farini and Massimo De Felici

Int. J. Dev. Biol. (2011) 55: 215-222

Generation of germ-line chimera zebrafish using primordial germ cells isolated from cultured blastomeres and cryopreserved embryoids

Yutaka Kawakami, Rie Goto-Kazeto, Taiju Saito, Takafumi Fujimoto, Shogo Higaki, Yoshiyuki Takahashi, Katsutoshi Arai and Etsuro Yamaha

Int. J. Dev. Biol. (2010) 54: 1493-1501

mgm 1, the earliest sex-specific germline marker in Drosophila, reflects expression of the gene esg in male stem cells

Adrian Streit, Luca Bernasconi, Pavel Sergeev, Alex Cruz and Monica Steinmann-Zwicky Int. J. Dev. Biol. (2002) 46: 159-166

Differentiation of mouse primordial germ cells into female or male germ cells N Nakatsuji and S Chuma

Int. J. Dev. Biol. (2001) 45: 541-548

The meiotic specific synaptonemal complex protein SCP3 is expressed by female and male primordial germ cells of the mouse embryo A D Di Carlo, G Travia and M De Felici Int. J. Dev. Biol. (2000) 44: 241-244
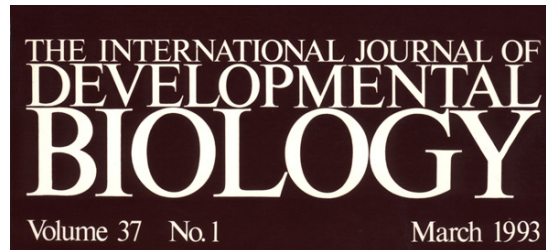

March 1993

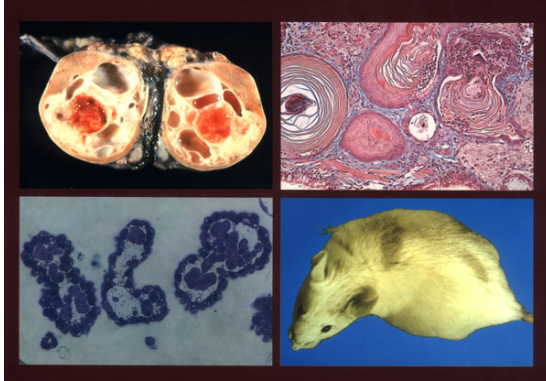

Developmental Aspects of Neoplasia
5 yr ISI Impact Factor $(2011)=2.959$

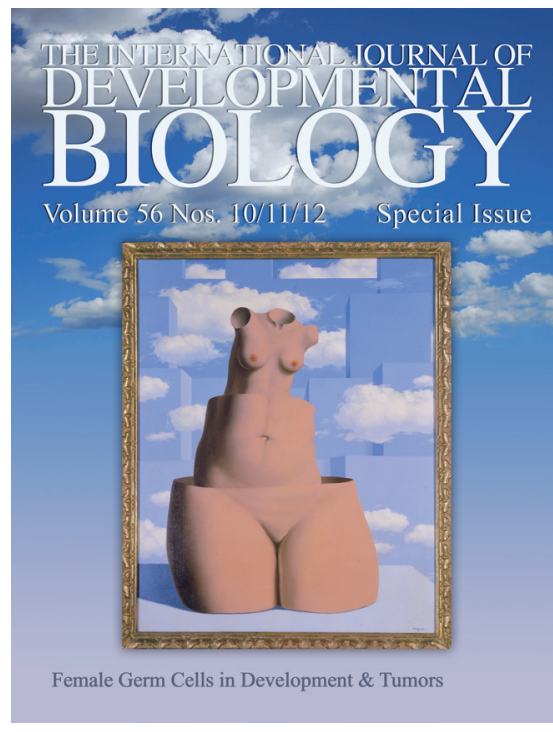

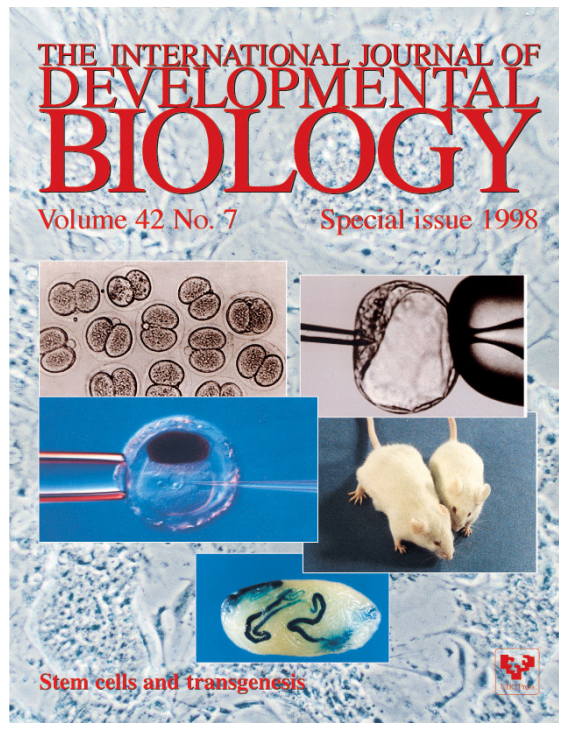

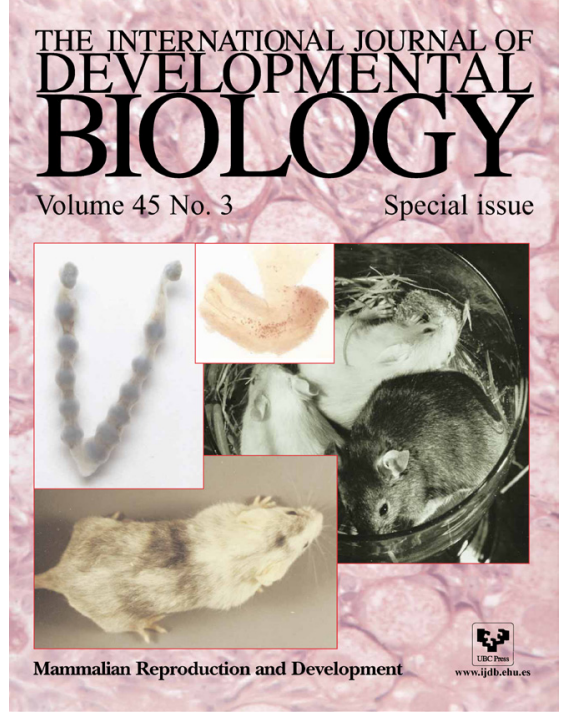

